ENGINEERING CHANGE NOTICE

1. ECN 649070

Page 1 of 2 Proj.

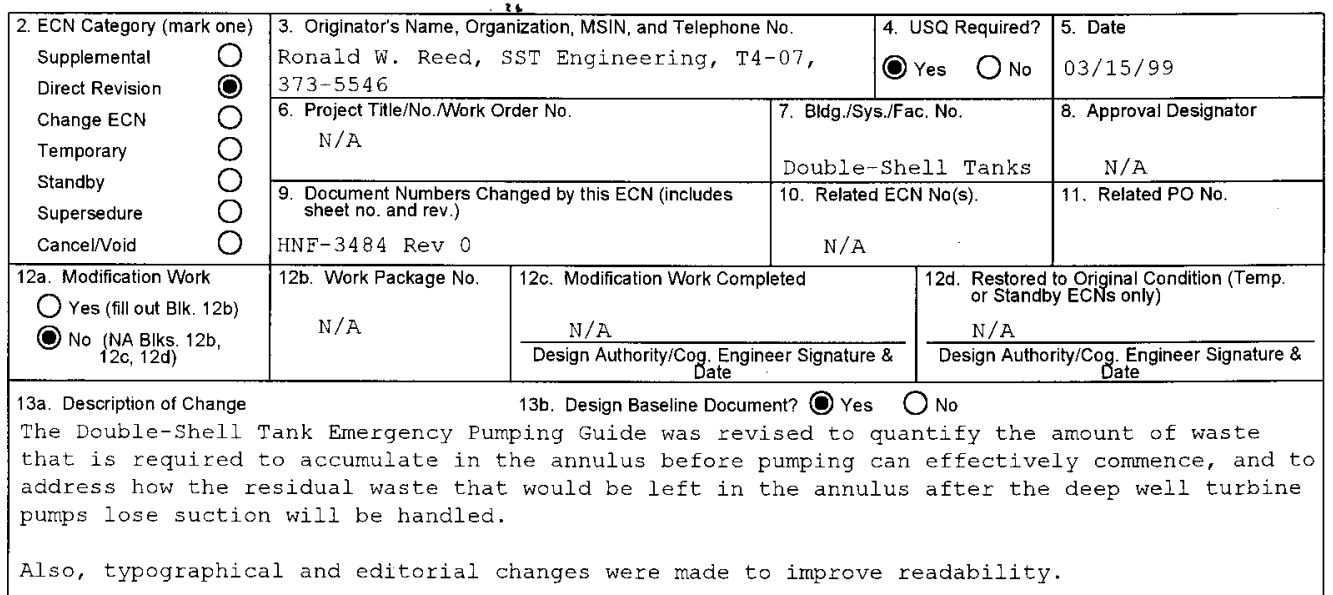

\begin{tabular}{|l|l}
\hline $\begin{array}{ll}\text { 14a. Justification (mark one) } \\
\text { Criteria Change }\end{array}$ & $\begin{array}{l}\text { 14b. Justification Details } \\
\text { The document wa }\end{array}$
\end{tabular}

O The document was revised to address items to the satisfaction of

Design Improvement

Environmental

Washington Department of Ecology.

Facility Deactivation

As-Found

This change to the document will not change collective dose since it has

Facilitate Const.

Const. Error/Omission

Design Error/Omission

O

O no impact on radiological sources, contamination control, or shielding.

15. Distribution (include name, MSIN, and no. of copies)

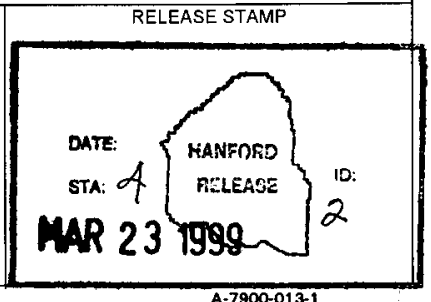




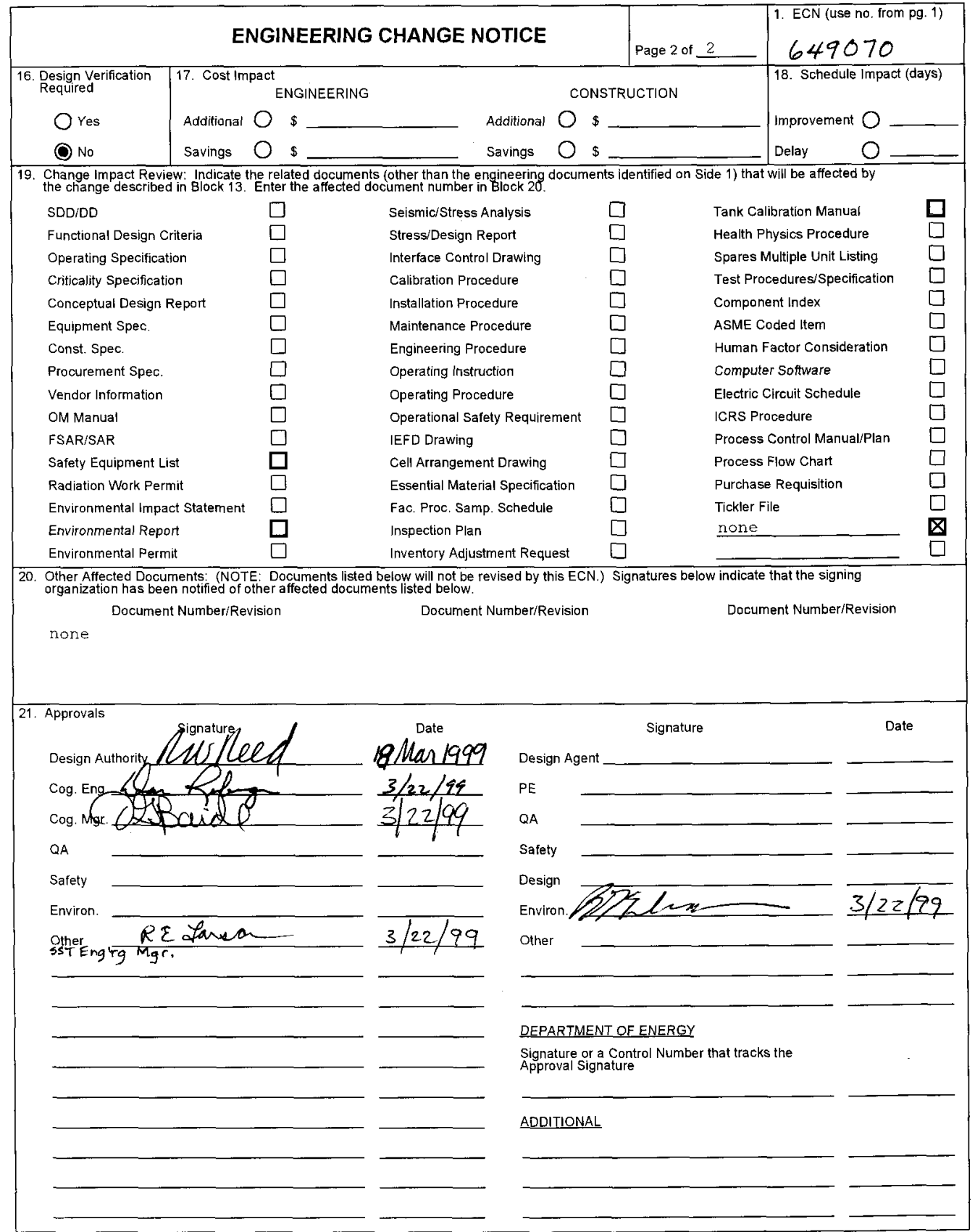




\title{
DOUBLE-SHELL TANK EMERGENCY PUMPING GUIDE
}

\author{
MH Brown \\ RW Reed
}

Lockheed Martin Hanford Company, Richland, WA 99352

U.S. Department of Energy Contract DE-AC06-96RL13200

EDT/ECN: 649070 UC: 2020

Org Code: 74800 Charge Code: 106773 BC20

B\&R Code: EW3130010 Total Pages: 44

Key Words: Double-Shell Tank, Emergency, Pumping, Guide, Secondary Containment, Annulus, Leak

Abstract: This Double-Shell Tank Emergency Pumping Guide provides the preplanning necessary to expeditiously remove any waste that may leak from the primary tank to the secondary tank for Hanford's 28 DSTs. The strategy is described, applicable emergency procedures are referenced, and transfer routes and pumping equipment for each tank are identified.

TRADEMARK DISCLAIMER. Reference herein to any specific commercial product, process, or service by trade name, trademark, manufacturer, or otherwise, does not necessarily constitute or imply its endorsement, recommendation, or favoring by the United States Government or any agency thereof or its contractors or subcontractors.

Printed in the United States of America. To obtain copies of this document, contact: Document Control Services, P.O. Box 950, Mailstop H6-08, Richland WA 99352, Phone (509) 372-2420; Fax (509) 376-4989.

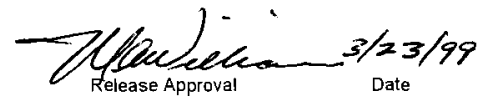

Release Stamp

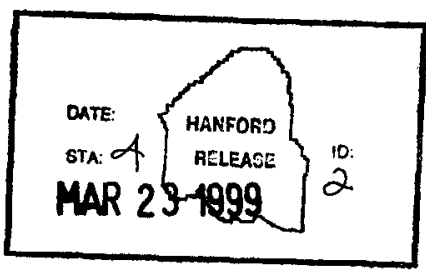

\section{Approved for Public Release}




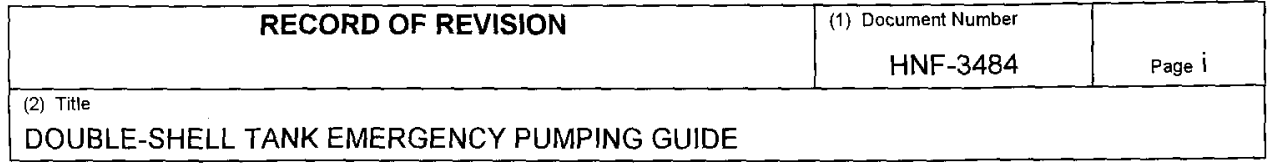

\begin{tabular}{|c|c|c|c|}
\hline \multicolumn{4}{|c|}{ CHANGE CONTROL RECORD } \\
\hline \multirow[t]{2}{*}{ (3) Revision } & \multirow[t]{2}{*}{ (4) Description of Change - Replace, Add, and Delete Pages } & \multicolumn{2}{|c|}{ Authorized for Release } \\
\hline & & (5) Cog. Engr. & $\begin{array}{r}\text { (6) Cog. Mgr. } \\
\text { Date }\end{array}$ \\
\hline$\overline{0}$ & $\begin{array}{l}\text { (7) Initial Issue per EDT } 618220 \text { on } 290 \text { ctober } \\
1999\end{array}$ & DW Regerger & DG Baide \\
\hline $1 \mathrm{RS}$ & $\begin{array}{l}\text { Added paragraph to Section } 1.1 \text { about } \\
\text { alternative study performed by ARES; added } \\
\text { Appendix D, and added description of Appendix } \\
\text { D to Section } 1.2 \text {; modified Section } 2.2 \text { to note } \\
\text { which DSTs have annulus pumps installed, and } \\
\text { to clarify routing from AY tanks' annulus back to } \\
\text { primary tank; added assumptions to Section } 3.2 \text {; } \\
\text { added paragraph to Section } 3.3 \text { to define } \\
\text { pumpable quantity and estimate residual waste; } \\
\text { added paragraph estimating time required to } \\
\text { commence pumping after leak discovery to } \\
\text { Section } 3.6 ; \text { made editorial corrections and } \\
\text { changes throughout to improve readability. }\end{array}$ & $\begin{array}{l}\text { DW Reberger } \\
\text { 10, felg } 3 / 22 / 44\end{array}$ & $\begin{array}{l}\text { DG Baide } \\
\text { (C) } 2 \text { Boido } \\
3 / 22 / 99\end{array}$ \\
\hline & $E C N-649070$ & & \\
\hline & & & \\
\hline & & & \\
\hline & & & \\
\hline & & & \\
\hline & & & \\
\hline
\end{tabular}




\section{DOUBLE-SHELL TANK}

\section{EMERGENCY PUMPING GUIDE}

Prepared for the United States Department of Energy

Lockheed Martin Hanford Corporation

P. O. Box 1500

Richland, Washington 99352 


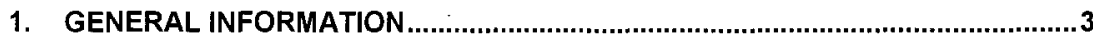

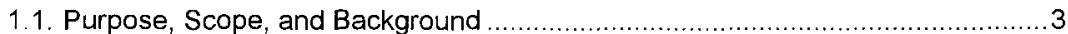

1.2. Summary of Information Provided ............................................................. 3

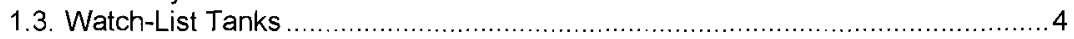

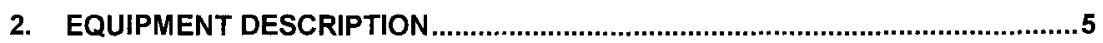

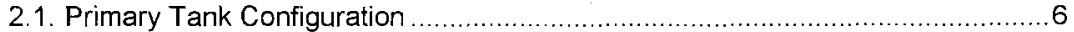

2.2. Secondary Containment Configuration ....................................................... 6

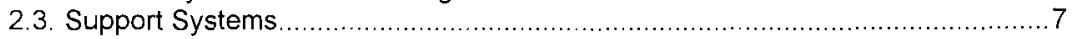

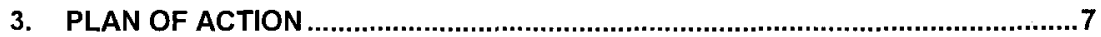

3.1. Regulatory Requirements Applicable to Leaking Double-Shell Tanks ..................7

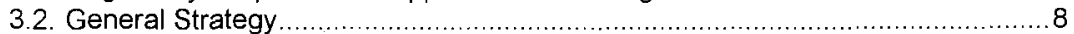

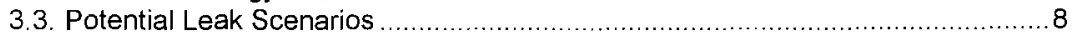

3.3.1. Strategy for Emergency Pumping after a Minor Leak ...............................9

3.3.2. Strategy for Emergency Pumping after a Moderate or Major Leak ..............10

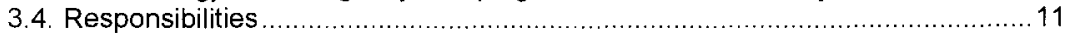

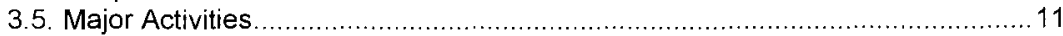

3.5.1. Pre-Emergency Pumping Planning Activities....................................... 11

3.5.2. Check Waste Characterization and Compatibility .................................. 12

3.4.3. Review/Prepare Safety Documentation ............................................. 12

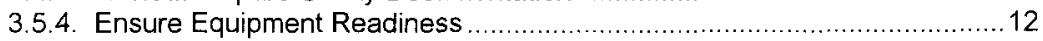

3.6. Estimated Time To Start Pumping Tanks .................................................. 13

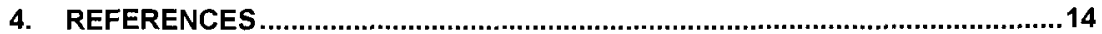

APPENDIX A - PROPOSED EMERGENCY PUMPING TRANSFER ROUTES From PRIMARY TANK To DESIGNATED AND ALTERNATE RECEIVER TANKS

APPENDIX B - LIST OF IMPLEMENTING PROCEDURES AND RELEVANT DRAWINGS

APPENDIX C - IDENTIFICATION AND LOCATION OF DST PUMPS AND JUMPERS THAT WOULD BE USED FOR EMERGENCY PUMPING

APPENDIX D - VOLUME OF LIQUID IN ANNULUS OF DOUBLE-SHELL TANK AT VARIOUS DEPTHS 


\section{GENERAL INFORMATION}

\subsection{Purpose, Scope, and Background}

The purpose of this plan is to provide as much preplanning as practical for pumping waste out of the annulus or secondary containment, of Double-Shell Tanks (DST). If the primary tank leaks, waste would accumulate in the secondary tank. For the purposes of this report, the terms "secondary tank" and "annulus" are used interchangeably. The preplanning will expedite emergency pumping and provide the basis for demonstrating that the leaked waste will be "removed from the secondary containment system within 24 hours, or in as timely a manner as is possible" as required by the Washington Administrative Code.

There are 177 large underground waste storage tanks in the Hanford 200 East and 200 West Areas. There are 149 single-shell tanks (SSTs), and 28 DSTs. The scope of this plan includes all 28 of the Hanford DSTs in AN, AP, AW, AY, AZ, and SY Tank Farms. The scope also includes the transfer lines, pump pits, valve pits, jumpers, transfer pumps, sump pumps, and procedures necessary to accomplish the emergency pumping.

An alternative study (ARES, 1999) was completed in March 1999, to identify a cost effective method of maintaining emergency annulus pumping equipment in a reliable condition. TWRS management is pursuing funds to refine and implement the study's recommendation. When funding becomes available, this Double-Shell Emergency Pumping Guide will be revised appropriately. Until that time, this Guide reflects use of existing equipment.

\subsection{Summary of Information Provided}

This guide contains a general description of the DSTs, and discussions of the requirements, strategy, transfer routes, procedures, and equipment that will be used to expeditiously respond to a leaking DST. References to statutory requirements are included. Information for each DST about the waste transfer routes, procedures, and equipment required for the transfers are contained or referenced in the appendices. These include:

\section{Appendix A: PROPOSED TRANSFER ROUTES.}

Contains a tabulated summary description of the proposed transfer route for each DST. Routes are included for transferring the waste from the primary tank to the designated receiver tank and to an alternate receiver tank. Tank AP-104 is the designated receiver tank, and AP-103 is the alternate receiver tank, for emergency transfers from all DSTs, except from the aging waste tanks $A Z-101$ and $A Z-102$. The designated and alternate receiver tanks for emergency transfers from $A Z-101$ and $A Z-102$ are $A Y-101$ and $A Y-$ 102 respectively. 
Appendix B: IMPLEMENTING PROCEDURES AND RELAVANT INFORMATION.

Contains a list of applicable transfer operating procedures and a list of Piping and Instrumentation Drawings (P\&ID) for each DST farm.

\section{Appendix C: INVENTORY AND STATUS OF REQUIRED EQUIPMENT.}

Contains a list of equipment that would be used to transfer waste out of a leaking DST.

\section{Appendix D: VOLUME OF LIQUID IN ANNULUS OF DOUBLE-SHELL TANK.}

Contains a sketch of a cross-section of the bottom of a typical DST, a list of assumptions, and a table of the volume of liquid that would be present in the annulus at various depths.

\subsection{Watch-List Tanks}

In response to Public Law 101-510, Section 3137, "Safety Measures for Waste Tanks at Hanford Nuclear Reservation," six DSTs are identified as Hydrogen/Flammable Gas Watch-List Tanks. The tanks are: AN-103, AN-104, AN-105, AW-101, SY-101, and SY103. These tanks are suspected to have a significant potential for hydrogen/flammable gas generation, entrapment, and episodic release.

Operating Specifications Document (OSD) OSD-T-151-00030 "Operating Specifications for Watch-List Tanks" requires that written approval must be obtained from Nuclear Safety and from DOE prior to transferring waste out of these six tanks. The OSD also requires written approval by the Secretary of Energy prior to transfer of waste into these six tanks. Because the Watch-List safety issues are a subject of ongoing research, the criteria for managing these tanks will continue to evolve. Therefore, a thorough evaluation of applicable requirements will need to be done at the time a leak is identified. 


\section{EQUIPMENT DESCRIPTION}

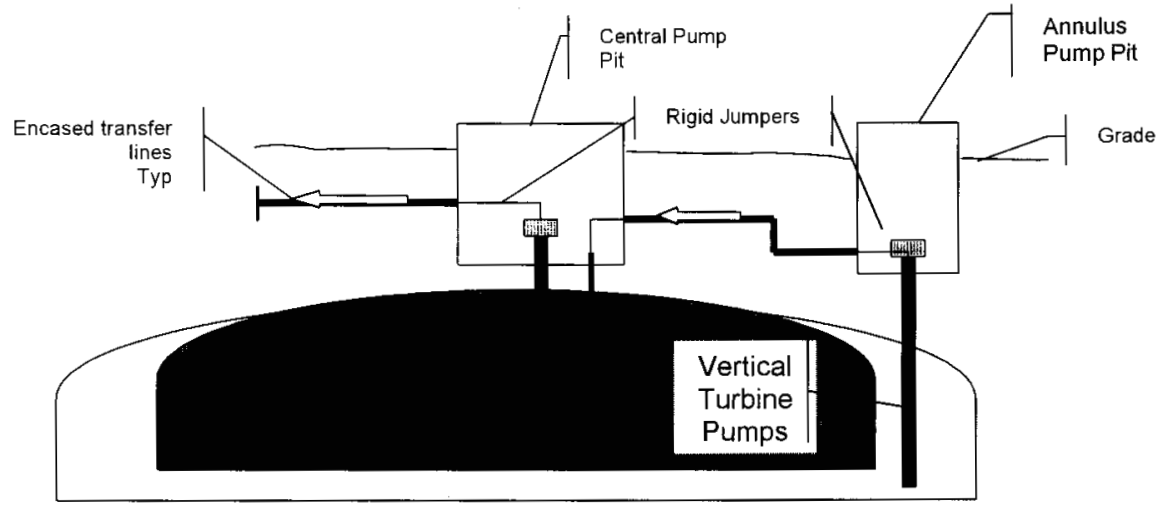

Figure 1 - Typical DST Configuration

All DSTs are similar in design and each has capacity of approximately 3.8 million Liters, (L) (1 million gal.). Slight differences in the tank and ancillary equipment, however, have occurred over the years from design improvements and because of the need to accommodate variations in waste composition. Twenty-eight DSTs are located in six farms, five farms in 200 East Area and one farm in 200 West Area. DSTs consist of a carbon steel primary tank and a carbon steel secondary tank encased by a protective reinforced concrete shell. The tanks contain a mixture of liquid, sludge, and salt cake waste with both radioactive and chemically toxic hazardous constituents. Liquids exist as supernatant (liquid above solids) and interstitial liquid (liquid filling the voids between solids) in the tanks. Sludge consists primarily of solids (hydrous metal oxides) precipitated by the neutralization of acid wastes. Salt cake, generally between the supernatant and sludge, consists of the various salts formed by the evaporation of water from the waste. These waste types do not necessarily exist as distinct layers and may be intermingled to differing degrees. Some sludges and salt cakes contain interstitial liquid and are relatively soft; others may be drier and harder.

Each tank is equipped with riser pipes that penetrate the concrete dome and the top of the primary or secondary tank. The risers provide access to the primary tank and to the annulus space for waste transfer operations, equipment installation or use, and monitoring. Most risers extend above grade. However, some risers are located under covered pits (e.g., Central Pump Pits, Annulus Pump Pits).

Pits provide access from the surface to process piping and tank risers and are the points where jumper (temporary piping systems), pumps, and other equipment are 
installed to establish waste transfer routes. A rigid jumper is a steel pipe that is fitted to specific wall nozzle configurations. The flexible jumpers are braided, stainless steel, flexible hose that permit connections to multiple wall nozzles.

There are three types of pumps used at TWRS to transfer waste into and out of DSTs. The types are: (1) jet pumps in combination with centrifugal pumps, with nominal capacities of 0.05 to $4.0 \mathrm{gpm}$, (2) submersible pumps, with nominal capacities of 10 to $30 \mathrm{gpm}$ and (3) transfer pumps, with nominal capacities of 100 to $250 \mathrm{gpm}$.

The components of a jet pump system located within a pump pit are a centrifugal pump, flexible or rigid jumpers, a flush line, and a flow totalizer. The centrifugal pump supplies motive fluid to the submerged jet pump system. Jet pumps are used to move liquid at very low rates.

A submersible pump can be used to raise large volumes of supernatant. The pump motor is below the pump intake and is submersed in the liquid being pumped.

Transfer pumps are typically installed in a pump pit, with the motor located in the pit and the intake located in the tank waste. Transfer pumps are normally deep-well, vertical turbine pumps, where the pump intake is a rigid pipe that extends to a fixed depth in the tank waste. Some transfer pumps have a floating intake, which is a flexible jumper connected to rigid pipe that does not extend into the waste.

\subsection{Primary Tank Configuration}

All DSTs have a Central Pump Pit which is approximately centered over the primary tank. The primary function of the pit is to provide confinement for a possible spray leak during waste transfers and to provide radiation shielding during waste transfers. The Central Pump Pits provide for access to the tank for supernatant filling or removal, slurry distribution, and mixing. Supernatant filling is accomplished through piping or jumpers connected to the riser. For supernatant removal, Central Pump Pits are designed to hold a deep-well turbine pump and piping or jumpers. Central Pump Pits for receiver tanks that store slurry are equipped with slurry distributors. The jumpers installed in the Central Pump Pit are either rigid or flexible jumpers. Transfer pumps are normally used to remove large volumes of supernatant. Jet pumps would be used to remove interstitial liquid because the liquid drains out of the sludge interstices too slowly to employ the transfer pumps. Before a jet pump system can be used to pump interstitial liquid, a stainless steel, salt screen must be installed in the waste to prevent solids from plugging the jet intakes.

\subsection{Secondary Containment Configuration}

The Annulus Pump Pit is located directly above the annulus and is connected to the annulus by a riser. The pit and riser provide access for pumping out any liquids that may accumulate in the annulus. There is just one annulus pump per tank farm that is interchangeable between the tanks within that farm, except for AW Farm. As of January 1999, there is an annulus pump installed in Tanks AN-107, AP-103, AY-101, AZ-101, 


\section{HNF-3484 Rev 1}

and $S Y-103$. These pumps were all original equipment and were subjected to an extensive 8-hr run-in test in the shop prior to installation. The tests included checking bearing temperature, flow rates, pressure, and vibration. The annulus pump designated for AW farm, pump \# 111-P10, is in the pump laydown area north of Building $2101 \mathrm{M}$ in the 200 East Area.

In the Annulus Pump Pit, a rigid or flex jumper assembly connects the annulus pump outlet to a $51-\mathrm{mm}$ (2-in) waste transfer line enclosed in a 102- $\mathrm{mm}$ (4-in) encasement. The encasement drains to the Annulus Pump Pit. The waste transfer line terminates at the Central Pump Pit of the tank. The two AY tanks, have an additional route back to the primary tank via a waste transfer route from the Annulus Pump Pit to a riser which connects directly to the primary tank.

\subsection{Support Systems}

Virtually all of the equipment and support systems that would be used for emergency pumping of DSTs are existing and are in nominal serviceable condition. There may be occasions where it would be necessary or practical to use a Jet Pump to remove waste, or drainable liquid, from the annulus of a leaking DST. In that case, equipment dedicated for emergency pumping of Single-Shell Tanks (SST) would be employed. That equipment consists of a jet pump, jumper, pumping and instrumentation control skid, flammable gas monitor, and over-ground piping. The TWRS Stabilization Program stages and stores this emergency pumping equipment for SSTs in HO-64-05192. See HNF-SD-WM-AP-005 "Single-Shell Tank Leak Emergency Pumping Guide" for details.

\section{PLAN OF ACTION}

\subsection{Regulatory Requirements Applicable to Leaking Double-Shell Tanks}

\section{CFR, Part 265.193 (c)(4) Containment and detection of releases.}

"... Sloped or otherwise designed or operated to drain and remove liquids resulting from leaks, spills, or precipitation. Spilled or leaked waste and accumulated precipitation must be removed from the secondary containment system within 24 hours, or in as timely a manner as is possible to prevent harm to human health or the environment, if removal of the released waste or accumulated precipitation cannot be accomplished within 24 hours."

WAC 173-303-640 (4)(iv) Tank systems.

"... Sloped or otherwise designed or operated to drain and remove liquids resulting from leaks, spills, or precipitation. Spilled or leaked waste and accumulated precipitation must be removed from the secondary containment system within twenty-four hours, or in as timely a manner as is possible to prevent harm to human health and the environment, if the owner or operator can demonstrate to the department that removal of the released waste or accumulated precipitation cannot be accomplished within twenty-four hours." 


\subsection{General Strategy}

The general strategy for emergency pumping a leaking DST is based on several assumptions. The more significant assumptions are:

- Tank AP-104 is the designated receiver tank for all DST emergency pumping, except the $A Z$ aging waste tanks. The designated receiver tank for aging waste will be AY-101.

- Tank AP-104 is and will be virtually empty. [NOTE: As of October 1998, Tank AP104 contained a heel of about 30,000 gallons.]

- Waste compatibility will not be an issue that causes a delay in the pumping.

- Tank AP-103 will be the alternate receiver tank in the event that AP-104 is not available or suitable for receiving an emergency transfer. Tank AY-102 will be the alternate receiver tank for aging waste from $A Z$ farm.

- To the maximum extent possible, existing double-contained, underground transfer lines will be used.

- Existing transfer pumps in the DST Central Pump Pits will be used to pump waste out of the primary tank.

- Existing annulus pumps in the DST farm will be used to pump waste out of the annulus back to the primary tank.

- The Saltwell Jet Pump and Emergency SST Skid may be used to remove waste from the primary tank and annulus.

- Leaks from SY-101 and SY-103 could be pumped to SY-102.

- About eight inches of liquid would need to accumulate in the bottom of the annulus before the annulus pump would automatically prime upon starting.

- Each DST annulus has a probe installed that is set to alarm if liquid is detected within the annulus.

- Each DST annulus has at least one probe installed that could be used to monitor liquid level in the annulus.

\subsection{Potential Leak Scenarios}

The best strategy for emergency pumping of a specific DST to "prevent harm to human health and the environment" will depend upon the rate or size of leak from the primary tank and upon whether the tank is a Watch-List tank. For purposes of this plan, leak scenarios are divided into three classes based upon the rate of the leak. The Minor Leak is treated separately, because pumpable quantities of waste are likely to be slow to accumulate. Moderate and Major Leaks are treated together, because the emergency response to them would be the same in either case.

The existing deep-well, vertical turbine annulus pump intakes are nominally two inches above the bottom of the secondary tank. The vendor recommends that the intake needs to be submerged about four to six inches before the pump can be primed. Assuming that eight inches of waste need to accumulate prior to starting the annulus pump, a "pumpable quantity" of waste in the annulus is approximately 11,360 liters $(3,000$ gallons.) See Appendix D for calculations of annulus volume. Assuming that a vortex two inches deep forms at the pump intake, the annulus pump would quit, or begin entraining air at the intake, when the waste level is about four inches. Assuming there 
HNF-3484 Rev 1

is no absorption of waste in the insulating concrete, about 5,300 liters (1,400 gallons) of residual waste will remain in the annulus. Methods to remove the residual waste include: some number of flush/dilution pump cycles; removing the high capacity turbine pump and installing a low capacity jet pump, submersible pump, or positive displacement pump designed for pumping down to fractions of an inch; and evaporating any moisture from the unpumpable residue with the HEPA filtered annulus ventilation system.

\subsubsection{Strategy for Emergency Pumping after a Minor Leak}

Scenario: Primary steel tank corrosion causes small breach. Waste dribbles into annulus and the annulus Continuous Air Monitor(CAM) alarms. Leak rate is so slow that dried waste will form on side of tank. Liquid accumulates in bottom of annulus very slowly over period of weeks or months, if at all. See Figure 1 for schematic depiction of minor leak.

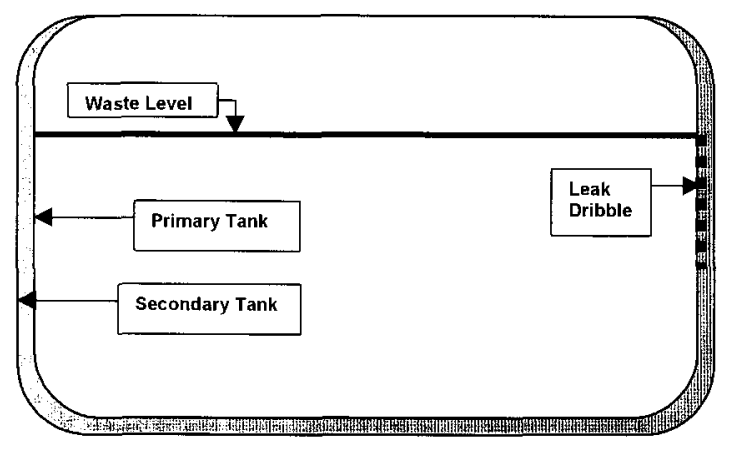

Figure 1. Schematic Diagram of Minor Leak

OBJECTIVE: Pump waste out of annulus within 24 hours or as timely as possible.

STRATEGY: Begin pumping primary tank contents via existing underground supernatant transfer pipelines with the existing transfer pump already installed in the Central Pump Pit. In parallel, install and prepare an annulus pump, if one is not already installed. Visually inspect annulus using a remote video camera mounted on a handheld wand, or using a remote video camera mounted on a robot similar to ones used for tank integrity assessments, to determine location of leak. Continue pumping the primary tank until the waste level is sufficiently below the leak path to accommodate adding the volume of waste in the annulus without rising above the leak path. When, and if, pumpable quantities of liquid accumulate in the annulus, pump annulus contents back to primary tank.

BENEFITS OF STRATEGY: For minor leaks this strategy minimizes the amount of waste that will be leaked to the annulus by using transfer pumps and pipelines already 
HNF-3484 Rev 1

installed and serviceable to lower the waste level in the primary tank. If pumpable quantities accumulate in the annulus, they will be removed as expeditiously as possible.

Once the primary tank waste level has been lowered below the leak path, and any pumpable quantities of waste in the annulus are removed, the emergency nature of the transfers can be downgraded and a permanent resolution determined. Removing as much of the waste as possible in a non-emergency mode is more likely to prevent harm to human health or the environment, than pumping all of the tank's contents in an emergency mode.

\subsubsection{Strategy for Emergency Pumping after a Moderate or Major Leak}

Scenario: A moderate or major leak occurs in the primary steel tank somewhere below the waste level. The waste levels in the primary tank and secondary tank equilibrate within hours or days. See Figure 2 for schematic depiction of a moderate to major leak.

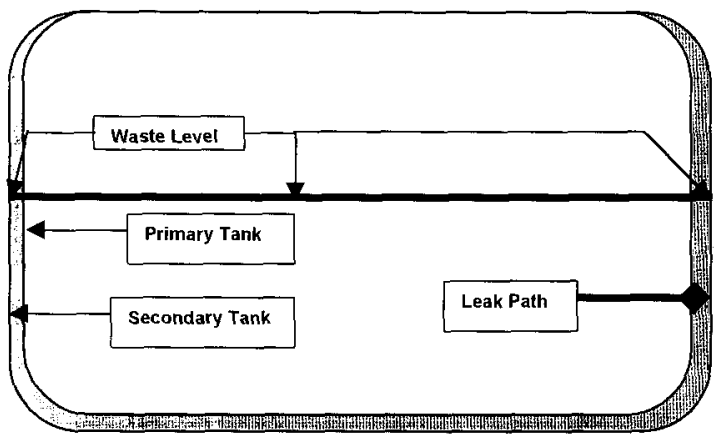

Figure 2. Schematic Diagram of Major Leak in Double-Shell Tank

OBJECTIVE: Pump waste out of annulus within 24 hours or as timely as possible.

STRATEGY: Begin pumping primary tank via existing underground supernatant transfer pipelines with the transfer pump installed in the leaking tank's Central Pump Pit. Monitor levels and material balances in primary tank to determine elevation of leak path on the sidewall or bottom of primary tank. In parallel with pumping of primary tank, install and prepare annulus pump. Monitoring and controlling the waste level in the annulus with respect to the waste level in the primary tank is important to prevent buoyant forces from floating the primary tank.

Once primary tank waste level is below the leak path, begin pumping waste from the annulus back to the primary tank via existing underground transfer lines from the Annulus Pump Pit to the Central Pump Pit. From the Central Pump Pit, the waste could be routed back to the primary tank. Since the primary tank transfer pumps have capacities equal or greater to the capacity of the annulus pumps, no additional waste will leak to the annulus. 
For leaking DSTs that do not have an installed primary transfer pump, an annulus pump would be installed. The annulus pump would be used to pump waste from the annulus to the Central Pump Pit. But, instead of directing the waste back to the primary tank there, the route would be jumpered through the Central Pump Pit to the same route used for transferring waste from the primary tank to the designated receiver tank.

BENEFITS OF STRATEGY: Most DSTs have primary transfer pumps installed. This strategy uses transfer pumps and pipelines already installed and serviceable so that pumping could be initiated more quickly. The leak will be stabilized faster and the portion of the annulus above the leak path will be pumped faster by using the higher capacity primary tank transfer pump than by using the annulus pump.

The waste in the annulus would be directed back to the primary tank where it would be pumped to the designated or alternate receiver tank via the established transfer route as necessary. This approach avoids having to modify the transfer procedure, or having to set up and arrange additional equipment and jumpers. Once the location of the leak is determined and the annulus is pumped, the emergency nature of the transfer could be downgraded. The waste remaining in the non-leaking portion of the tank could be left in the tank or pumped to some other tank, depending upon the best solution under the circumstances. Removing as much of the waste as possible in a non-emergency mode is more likely to prevent harm to human health or the environment, than pumping all of the tanks contents in an emergency mode.

If the leak path is near the bottom of the tank, then this approach will result in removing waste from the annulus in the most timely manner because the highest capacity pump and transfer routes are employed.

\subsection{Responsibilities}

The responsibilities for various actions and activities associated with emergency pumping are detailed in the specific emergency pumping procedures. See Appendix B. Because a leaking tank may constitute both a safety issue and an environmental issue, the emergency response must be planned in cooperation with the Richland Office of the DOE (RL), and the Washington State Department of Ecology, and the Washington State Department of Health.

\subsection{Major Activities}

\subsubsection{Pre-Emergency Pumping Planning Activities}

- Hold a kick-off meeting to bring together all required participants to assign responsibilities and action items necessary to initiate pumping.

- Walk-down facility to identify needed repairs, or scheduled maintenance that may need to be accelerated. 
HNF-3484 Rev 1

- Review applicable operating and emergency transfer procedures and validate for specific conditions or circumstances if necessary.

\subsubsection{Check Waste Characterization and Compatibility}

Before waste is transferred, compatibility tests or assessments are performed on the waste in both the supply and receiver tanks to ensure that undesirable chemical reactions do not occur. The document "Data Quality Objectives for the Waste Compatibility Program" (HNF-SD-WM-DQO-001, Rev. 0) discusses the criteria used to assess the compatibility of wastes before they are mixed. Most of the transfers discussed in this plan involve moving waste only to TK-104-AP, which contains roughly 30,000 gallons of a very dilute waste that should pose no compatibility problems. Transfers of waste from the six DST Watch-List tanks, require special approvals per OSD-T-151-00030.

In preparation for final waste retrieval, there is an ongoing Characterization Program within TWRS to fully document the chemical and physical characteristics of the waste stored in each tank. This data will be used if available.

\subsubsection{Review/Prepare Safety Documentation}

All provisions of HNF-SD-WM-BIO-001, HNF-SD-WM-TSR-006 must be met during emergency pumping activities. The requirements of OSD-T-151-00030 would also be met if a DST Watch-List tank is involved.

Provisions of Occupational Safety and Health procedures, Radiation Protection Procedures, and Tank Farm Health and Safety Plan, apply to all work performed. Health Physics shall assist in issuing special Radiation Work Permits as needed to safely pump waste from the DST primary or secondary tanks.

The emergency pumping procedures (See Appendix B) will be preapproved and will have unreviewed safety question (USQ) screening/determinations completed to assure that emergency pumping can be executed within the existing Authorization Basis. The USQ procedure is defined in the TWRS Administration Manual HNF-IP-0842, Volume IV, Section 5.4 .

\subsubsection{Ensure Equipment Readiness}

Confirm proposed transfer route, destination of the waste, heat trace operability. A proposed transfer route for each tank is identified in Appendix A.

Obtain and install necessary jumpers in valve pits, if required. Ensure availability and readiness of transfer pumps. 
HNF-3484 Rev 1

\subsection{Estimated Time To Start Pumping Tanks}

To the extent practical, all equipment and documentation necessary to perform emergency transfers from the primary and secondary tanks of the DSTs have been prepared ahead of time.

The regulations require removing "Spilled or leaked waste and accumulated precipitation ... from the secondary containment system within twenty-four hours, or in as timely a manner as is possible to prevent harm to human health and the environment, if the owner or operator can demonstrate to the department that removal of the released waste or accumulated precipitation cannot be accomplished within twenty-four hours." In most cases the nature of the leak will make a 24-hour response impossible.

An annulus pump is installed in a tank in each DST Tank Farm, except for AW Tank Farm. The annulus pump for the AW Tank Farm is in the 200E pump laydown area. Chances are 5 in 28 , that a leak will occur in a tank that already has an annulus pump installed. If a leak occurs in a tank that does not have an annulus pump already installed, the pump installed in the same farm will be moved to the leaking DST. The major tasks involved in moving an annulus pump from one DST to another DST within the same tank farm include: preparing and approving a work package, validating the transfer procedures(s), performing dome loading calculations, preparing a critical lift procedure for the crane, setting up the crane, removing pit cover blocks, removing the pump, walking the crane to the leaking tank, inserting the pump, installing necessary pipe jumpers, making electrical connections, and closing the pit. A rough order of magnitude for the time required to complete the major tasks necessary to move an annulus pump is two to three weeks. If the leaking tank were a Watch List Tank, an undetermined additional time would be required for DOE-RL and DOE-HDQTRS approval. 


\section{REFERENCES}

40CFR, Part 265.193 (c)(4) "Containment and detection of releases."

HNF-IP-0842, TWRS Administration Manual, Volume IV, Section 5.4. "Unreviewed Safety Questions."

HNF-SD-WM-AP-005 "Single-Shell Tank Leak Emergency Pumping Guide."

HNF-SD-WM-DQO-001, Rev. 0, "Data Quality Objectives for the Waste Compatibility Program."

HNF-SD-WM-TSR-006, "Tank Waste Remediation System Technical Safety Requirements."

HNF-SD-WM-BIO-001, "Tank Waste Remediation System Basis for Interim Operation."

OSD-T-151-00030, "Operating Specifications for Watch-List Tanks."

Public Law 101-510, Section 3137, "Safety Measures for Waste Tanks at Hanford Nuclear Reservation."

Tank Farm Health \& Safety Plan

WAC 173-303-640 (4)(iv) "Tank systems."

WHC-SP-1137, "Preventative Maintenance Plan for Emergency Pumping Trailers."

WHC-SD-WM-OTP-027, "Jet-Pump Jumper Pressure Test."

Report No. 9905303-001, "Double-Shell Tank Annulus Pumping Alternative Evaluation," by ARES Corporation, March 1999. 
HNF-3484 Rev. 1

APPENDIXA

\section{APPENDIX A}

PROPOSED EMERGENCY PUMPING TRANSFER ROUTES

From PRIMARY TANK TO

DESIGNATED AND ALTERNATE RECEIVER TANKS 


\section{HNF-3484 Rev. 1}

APPENDIXA

The proposed transfer routes described below are for the emergency pumping of the primary tanks. The transfer pipelines for pumping all DST primary tanks are pipe-inpipe, or encased pipelines.

The proposed route for emergency pumping of the annulus, which are not tabulated in this Appendix, will be from the Annulus Pump Pit through rigid/flex jumpers to an encased, below-grade pipeline to the Central Pump Pit, and then from the Central Pump Pit to the primary tank via the tank return. The transfer pipelines from the Annulus Pump Pit to the Central Pump Pit for all DST tanks are pipe-in-pipe, or encased pipelines except for AY-101, AY-102, and AZ-102. The two tanks in AY farm have direct-buried, unencased pipelines from the annulus pump pits to the central pump pits and to a riser that leads directly into the primary tanks. Tank AZ-102 has a directburied, unencased pipeline from the annulus pump pit to the central pump pit.

\section{TRANSFER ROUTES from 241-AN PRIMARY TANKS TO DESIGNATED RECEIVER TANK 241-AP-104}

\begin{tabular}{|c|c|}
\hline \multicolumn{2}{|c|}{ TK-101-AN Transfer Route to Designated Receiver Tank } \\
\hline 241-AN 01A Pump Pit & $\begin{array}{l}\text { Transfer Pump through Rigid Jumper to } \\
\text { Nozzle A to Line SN } 261\end{array}$ \\
\hline 241-AN-B Valve Pit & $\begin{array}{l}\text { Nozzle R15 through Flex/Rigid Jumper to } \\
\text { Nozzle R2 via E to Line SN } 260\end{array}$ \\
\hline 241-AZ-02B Pump Pit & $\begin{array}{c}\text { Nozzle U7 through Flex Jumper to Nozzle } \\
\text { U5 to Line SN } 600\end{array}$ \\
\hline 241-AX-A Valve Pit & $\begin{array}{l}\text { Nozzle L16 through Flex Jumper to Nozzle } \\
\text { L1 to Line SN 214/201 }\end{array}$ \\
\hline 241-A-A Valve Pit & $\begin{array}{l}\text { Nozzle L1 through Rigid Jumper to Nozzle } \\
\text { L2 to Line SN } 220\end{array}$ \\
\hline 241-AW-A Valve Pit & $\begin{array}{l}\text { Nozzle L2 through Flex/Rigid Jumper to } \\
\text { Nozzle L1 via D to Line SN } 267\end{array}$ \\
\hline 241-AW-02A Pump Pit & $\begin{array}{l}\text { Nozzle J through Rigid Jumper to Nozzle } \\
\qquad \text { to Line SN } 609\end{array}$ \\
\hline 241-AP Valve Pit & $\begin{array}{l}\text { Nozzle } 14 \text { through Rigid Jumpers to } \\
\text { Nozzle } 20 \text { via } P, M, H, \& J \text { to Line SN } 614\end{array}$ \\
\hline TK 104 AP-04A Pump Pit & $\begin{array}{c}\text { Nozzle A through Rigid Jumper to Nozzle } \\
E \text { (Tank Return) }\end{array}$ \\
\hline
\end{tabular}

\begin{tabular}{|c|c|}
\hline \multicolumn{2}{|c|}{ TK-102-AN Transfer Route to Designated Receiver Tank } \\
\hline 241 -AN 02A Pump Pit & $\begin{array}{r}\text { Transfer Pump through Rigid Jumper to } \\
\text { Nozzle A to Line SN 262 }\end{array}$ \\
\hline 241 -AN-B Valve Pit & $\begin{array}{c}\text { Nozzle R16 through Flex/Rigid Jumper to } \\
\text { Nozzle R2 via E to Line SN 260 }\end{array}$ \\
\hline Same as 101-AN to AP-104 & \\
\hline
\end{tabular}


HNF-3484 Rev. 1

APPENDIX A

\begin{tabular}{|c|c|}
\hline \multicolumn{2}{|c|}{ TK-103-AN Transfer Route to Designated Receiver Tank } \\
\hline 241-AN 03A Pump Pit & $\begin{array}{l}\text { Transfer Pump through Rigid Jumper to } \\
\text { Nozzle A to Line SN } 263\end{array}$ \\
\hline 241-AN-B Valve Pit & $\begin{array}{l}\text { Nozzle R14 through Flex/Rigid Jumper to } \\
\text { Nozzle R2 via E to Line SN } 260\end{array}$ \\
\hline Same as 101-AN to AP-104 & \\
\hline \multicolumn{2}{|c|}{ TK-104-AN Transfer Route to Designated Receiver Tank } \\
\hline 241-AN 04A Pump Pit & $\begin{array}{l}\text { Transfer Pump through Rigid Jumper to } \\
\text { Nozzle A to Line SN } 264\end{array}$ \\
\hline 241-AN-A Valve Pit & $\begin{array}{l}\text { Nozzle L15 through Flex/Rigid Jumper to } \\
\text { Nozzle L19 via D to Line SN } 268\end{array}$ \\
\hline 241-AN-B Valve Pit & $\begin{array}{l}\text { Nozzle R19 through Rigid Jumper to } \\
\text { Nozzle R2 to Line SN } 260\end{array}$ \\
\hline Same as $101-\mathrm{AN}$ to $\mathrm{AP}-104$ & \\
\hline \multicolumn{2}{|c|}{ TK-105-AN Transfer Route to Designated Receiver Tank } \\
\hline 241-AN 05A Pump Pit & $\begin{array}{l}\text { Transfer Pump through Rigid Jumper to } \\
\text { Nozzle A to Line SN } 265\end{array}$ \\
\hline 241-AN-A Valve Pit & $\begin{array}{l}\text { Nozzle L16 through FlexiRigid Jumper to } \\
\text { Nozzle L19 via D to Line SN } 268\end{array}$ \\
\hline 241-AN-B Valve Pit & $\begin{array}{l}\text { Nozzle R19 through Rigid Jumper to } \\
\text { Nozzle R2 to Line SN } 260\end{array}$ \\
\hline Same as 101-AN to AP-104 & \\
\hline \multicolumn{2}{|c|}{ TK-106-AN Transfer Route to Designated Receiver Tank } \\
\hline 241-AN 06A Pump Pit & $\begin{array}{l}\text { Transfer Pump through Rigid Jumper to } \\
\text { Nozzle A to Line SN } 266\end{array}$ \\
\hline 241-AN-A Valve Pit & $\begin{array}{l}\text { Nozzle L14 through Flex/Rigid Jumper to } \\
\text { Nozzie L19 via D to Line SN } 268\end{array}$ \\
\hline 241-AN-B Valve Pit & $\begin{array}{l}\text { Nozzle R19 through Rigid Jumper to } \\
\text { Nozzle R2 to Line SN } 260\end{array}$ \\
\hline Same as 101-AN to AP-104 & \\
\hline
\end{tabular}


HNF-3484 Rev. 1

APPENDIXA

\section{TRANSFER ROUTES from 241-AN PRIMARY TANKS TO ALTERNATE RECEIVER TANK 241-AP-103}

\begin{tabular}{|c|c|}
\hline \multicolumn{2}{|c|}{ TK-101-AN Transfer Route to Alternate Receiver Tank } \\
\hline 241-AN 01A Pump Pit & $\begin{array}{l}\text { Transfer Pump through Rigid Jumper to } \\
\text { Nozzle A to Line SN } 261\end{array}$ \\
\hline 241-AN-B Valve Pit & $\begin{array}{l}\text { Nozzle R15 through Flex/Rigid Jumper to } \\
\text { Nozzle R2 via E to Line SN } 260\end{array}$ \\
\hline 241-AZ-02B Pump Pit & $\begin{array}{l}\text { Nozzle U7 through Flex Jumper to Nozzle } \\
\text { U5 to Line SN } 600\end{array}$ \\
\hline 241-AX-A Valve Pit & $\begin{array}{l}\text { Nozzle L16 through Flex Jumper to Nozzle } \\
\text { L1 to Line SN 214/201 }\end{array}$ \\
\hline 241-A-A Valve Pit & $\begin{array}{l}\text { Nozzle L1 through Rigid Jumper to Nozzle } \\
\text { L2 to Line SN } 220\end{array}$ \\
\hline 241-AW-A Valve Pit & $\begin{array}{l}\text { Nozzle L2 through Flex/Rigid Jumper to } \\
\text { Nozzle L1 via D to Line SN } 267\end{array}$ \\
\hline 241-AW-02A Pump Pit & $\begin{array}{l}\text { Nozzle } J \text { through Rigid Jumper to Nozzle } \\
\qquad \text { to Line SN } 609\end{array}$ \\
\hline 241-AP Valve Pit & $\begin{array}{l}\text { Nozzle } 14 \text { through Rigid Jumpers to } \\
\text { Nozzle } 17 \text { via } P, M, \& H \text { to Line SN } 613\end{array}$ \\
\hline TK 103 AP-03A Pump Pit & $\begin{array}{l}\text { Nozzle A through Rigid Jumper to Nozzle } \\
E \text { (Tank Return) }\end{array}$ \\
\hline \multicolumn{2}{|c|}{ TK-102-AN Transfer Route to Alternate Receiver Tank } \\
\hline 241-AN 02A Pump Pit & $\begin{array}{l}\text { Transfer Pump through Rigid Jumper to } \\
\text { Nozzle A to Line SN } 262\end{array}$ \\
\hline 241-AN-B Valve Pit & $\begin{array}{l}\text { Nozzle R16 through Flex/Rigid Jumper to } \\
\text { Nozzle R2 via E to Line SN } 260\end{array}$ \\
\hline Same as $101-\mathrm{AN}$ to $\mathrm{AP}-10$ & \\
\hline \multicolumn{2}{|c|}{ TK-103-AN Transfer Route to Alternate Receiver Tank } \\
\hline 241-AN 03A Pump Pit & $\begin{array}{l}\text { Transfer Pump through Rigid Jumper to } \\
\text { Nozzle A to Line SN } 263\end{array}$ \\
\hline 241-AN-B Valve Pit & $\begin{array}{l}\text { Nozzle R14 through Flex/Rigid Jumper to } \\
\text { Nozzle R2 via E to Line SN } 260\end{array}$ \\
\hline \multicolumn{2}{|l|}{ Same as 101-AN to AP-103 } \\
\hline \multicolumn{2}{|c|}{ TK-104-AN Transfer Route to Alternate Receiver Tank } \\
\hline 241-AN 04A Pump Pit & $\begin{array}{l}\text { Transfer Pump through Rigid Jumper to } \\
\text { Nozzle A to Line SN } 264\end{array}$ \\
\hline 241-AN-A Valve Pit & $\begin{array}{l}\text { Nozzle L15 through Flex/Rigid Jumper to } \\
\text { Nozzle L19 via D to Line SN } 268\end{array}$ \\
\hline $241-A N-B$ Valve Pit & $\begin{array}{l}\text { Nozzle R19 through Rigid Jumper to } \\
\text { Nozzle R2 to Line SN } 260\end{array}$ \\
\hline Same as 101-AN to AP-10 & \\
\hline
\end{tabular}


HNF-3484 Rev. 1

APPENDIXA

\begin{tabular}{|c|c|}
\hline \multicolumn{2}{|c|}{ TK-105-AN Transfer Route to Alternate Receiver Tank } \\
\hline 241-AN 05A Pump Pit & $\begin{array}{l}\text { Transfer Pump through Rigid Jumper to } \\
\text { Nozzle A to Line SN } 265\end{array}$ \\
\hline 241-AN-A Valve Pit & $\begin{array}{l}\text { Nozzle L16 through Flex/Rigid Jumper to } \\
\text { Nozzle L19 via D to Line SN } 268\end{array}$ \\
\hline 241-AN-B Valve Pit & $\begin{array}{l}\text { Nozzle R19 through Rigid Jumper to } \\
\text { Nozzle R2 to Line SN } 260\end{array}$ \\
\hline Same as $101-\mathrm{AN}$ to $\mathrm{AP}-103$ & \\
\hline \multicolumn{2}{|c|}{ TK-106-AN Transfer Route to Alternate Receiver Tank } \\
\hline 241-AN 06A Pump Pit & $\begin{array}{l}\text { Transfer Pump through Rigid Jumper to } \\
\text { Nozzle A to Line SN } 266\end{array}$ \\
\hline 241-AN-A Valve Pit & $\begin{array}{l}\text { Nozzle L14 through Flex/Rigid Jumper to } \\
\text { Nozzle L19 via D to Line SN } 268\end{array}$ \\
\hline 241-AN-B Valve Pit & $\begin{array}{l}\text { Nozzle R19 through Rigid Jumper to } \\
\text { Nozzle R2 to Line SN } 260\end{array}$ \\
\hline Same as $101-\overline{A N}$ to $A \bar{P}-103$ & \\
\hline
\end{tabular}

\section{TRANSFER ROUTES from 241-AP PRIMARY TANKS TO DESIGNATED RECEIVER TANK 241-AP-104}

\begin{tabular}{|c|c|}
\hline \multicolumn{2}{|c|}{ TK-101-AP Transfer Route to Designated Receiver Tank } \\
\hline 241-AP-01A Pump Pit & $\begin{array}{l}\text { Transfer Pump through Rigid Jumper to } \\
\text { Nozzle A to Line SN } 611\end{array}$ \\
\hline 241-AP Valve Pit & $\begin{array}{c}\text { Nozzle } 18 \text { through to Nozzle } 20 \text { via } \mathrm{J} \text { to } \\
\text { Line SN } 614\end{array}$ \\
\hline 241-AP-04A Pump Pit & $\begin{array}{c}\text { Nozzle A through Rigid jumper to Nozzle } \bar{E} \\
\text { (Tank Return) }\end{array}$ \\
\hline \multicolumn{2}{|c|}{ TK-102-AP Transfer Route to Designated Receiver Tank } \\
\hline 241-AP O2A Pump Pit & $\begin{array}{l}\text { Transfer Pump through Rigid Jumper to } \\
\text { Nozzle A to Line SN } 612\end{array}$ \\
\hline 241-AP Valve Pit & $\begin{array}{l}\text { Nozzle } 19 \text { through to Nozzle } 20 \text { to Line SN } \\
614\end{array}$ \\
\hline 241-AP-04A Pump Pit & $\begin{array}{l}\text { Nozzle A through Rigid jumper to Nozzle } \mathrm{E} \\
\text { (Tank Return) }\end{array}$ \\
\hline \multicolumn{2}{|c|}{ TK-103-AP Transfer Route to Designated Receiver Tank } \\
\hline 241-AP 03A Pump Pit & $\begin{array}{l}\text { Transfer Pump through Rigid Jumper to } \\
\text { Nozzle A to Line SN } 613\end{array}$ \\
\hline 241-AP Valve Pit & $\begin{array}{l}\text { Nozzle } 17 \text { through to Nozzle } 20 \text { to Line SN } \\
614\end{array}$ \\
\hline 241-AP-04A Pump Pit & $\begin{array}{l}\text { Nozzle A through Rigid jumper to Nozzle } \mathrm{E} \\
\text { (Tank Return) }\end{array}$ \\
\hline
\end{tabular}


TK-105-AP Transfer Route to Designated Receiver Tank

\begin{tabular}{|c|c|}
\hline 241-AP 05A Pump Pit & $\begin{array}{l}\text { Transfer Pump through Rigid Jumper to } \\
\text { Nozzle A to Line SN } 615\end{array}$ \\
\hline 241-AP Valve Pit & $\begin{array}{l}\text { Nozzle } 24 \text { through to Nozzle } 20 \text { via } K, D \text {, } \\
C, N, P, M, H, \& \text { to Line } S N 614\end{array}$ \\
\hline 241-AP-04A Pump Pit & $\begin{array}{c}\text { Nozzle A through Rigid jumper to Nozzle E } \\
\text { (Tank Return) }\end{array}$ \\
\hline \multicolumn{2}{|c|}{ TK-106-AP Transfer Route to Designated Receiver Tank } \\
\hline 241-AP 06A Pump Pit & $\begin{array}{l}\text { Transfer Pump through Rigid Jumper to } \\
\text { Nozzle A to Line SN } 616\end{array}$ \\
\hline 241-AP Valve Pit & $\begin{array}{l}\text { Nozzle } 21 \text { through to Nozzle } 20 \text { via } D, C \\
\text { N, P, M } H \text {, \& J to Line SN } 614\end{array}$ \\
\hline 241-AP-04A Pump Pit & $\begin{array}{l}\text { Nozzle A through Rigid jumper to Nozzle E } \\
\text { (Tank Return) }\end{array}$ \\
\hline \multicolumn{2}{|c|}{ TK-107-AP Transfer Route to Designated Receiver Tank } \\
\hline 241-AP 07A Pump Pit & $\begin{array}{c}\text { Transfer Pump through Rigid Jumper to } \\
\text { Nozzle A to Line SN } 617\end{array}$ \\
\hline 241-AP Valve Pit & $\begin{array}{l}\text { Nozzle } 23 \text { through to Nozzle } 20 \text { via } K, D \\
C, N, P, M, H, \& \text { J to Line SN } 614\end{array}$ \\
\hline 241-AP-04A Pump Pit & $\begin{array}{c}\text { Nozzie A through Rigid jumper to Nozzle E } \\
\text { (Tank Return) }\end{array}$ \\
\hline \multicolumn{2}{|c|}{ TK-108-AP Transfer Route to Designated Receiver Tank } \\
\hline 241-AP 08A Pump Pit & $\begin{array}{l}\text { Transfer Pump through Rigid Jumper to } \\
\text { Nozzle A to Line SN } 618\end{array}$ \\
\hline 241-AP Valve Pit & $\begin{array}{l}\text { Nozzle } 22 \text { through to Nozzle } 20 \text { via } D, C \\
\text { N, P M } M \text {, \& J to Line SN } 614\end{array}$ \\
\hline 241-AP-04A Pump Pit & $\begin{array}{c}\text { Nozzle A through Rigid jumper to Nozzle E } \\
\text { (Tank Return) }\end{array}$ \\
\hline
\end{tabular}




\section{HNF-3484 Rev. 1 \\ APPENDIX A}

TRANSFER ROUTES from 241-AP PRIMARY TANKS

TO ALTERNATE RECEIVER TANK 241-AP-103

\begin{tabular}{|c|c|}
\hline \multicolumn{2}{|c|}{ TK-101-AP Transfer Route to Alternate Receiver Tank } \\
\hline 241-AP-01A Pump Pit & $\begin{array}{l}\text { Transfer Pump through Rigid Jumper to } \\
\text { Nozzle A to Line SN } 611\end{array}$ \\
\hline 241-AP Valve Pit & $\begin{array}{l}\text { Nozzle } 18 \text { through to Nozzle } 17 \text { to Line SN } \\
613\end{array}$ \\
\hline 241-AP-03A Pump Pit & $\begin{array}{c}\text { Nozzle A through Rigid jumper to Nozzle } \mathrm{E} \\
\text { (Tank Return) }\end{array}$ \\
\hline \multicolumn{2}{|c|}{ TK-102-AP Transfer Route to Alternate Receiver Tank } \\
\hline 241-AP-02A Pump Pit & $\begin{array}{l}\text { Transfer Pump through Rigid Jumper to } \\
\text { Nozzle A to Line SN } 612\end{array}$ \\
\hline 241-AP Valve Pit & $\begin{array}{c}\text { Nozzle } 19 \text { through to Nozzle } 17 \text { via } \mathrm{J} \text { to } \\
\text { Line SN } 613\end{array}$ \\
\hline 241-AP-03A Pump Pit & $\begin{array}{c}\text { Nozzle A through Rigid jumper to Nozzle E } \\
\text { (Tank Return) }\end{array}$ \\
\hline \multicolumn{2}{|c|}{ TK-104-AP Transfer Route to Alternate Receiver Tank } \\
\hline 241-AP-04A Pump Pit & $\begin{array}{c}\text { Transfer Pump through Rigid Jumper to } \\
\text { Nozzle A to Line SN } 614\end{array}$ \\
\hline 241-AP Valve Pit & $\begin{array}{c}\text { Nozzle } 20 \text { through to Nozzle } 17 \text { via J to } \\
\text { Line SN } 613\end{array}$ \\
\hline 241-AP-03A Pump Pit & $\begin{array}{c}\text { Nozzle A through Rigid jumper to Nozzle E } \\
\text { (Tank Return) }\end{array}$ \\
\hline \multicolumn{2}{|c|}{ TK-105-AP Transfer Route to Alternate Receiver Tank } \\
\hline 241-AP-05A Pump Pit & $\begin{array}{c}\text { Transfer Pump through Rigid Jumper to } \\
\text { Nozzle A to Line SN } 615\end{array}$ \\
\hline 241-AP Valve Pit & $\begin{array}{l}\text { Nozzle } 24 \text { through to Nozzle } 17 \text { via } K, D \\
C, N, P, M, \& H \text { to Line } S N 613\end{array}$ \\
\hline 241-AP-03A Pump Pit & $\begin{array}{c}\text { Nozzle A through Rigid jumper to Nozzle E } \\
\text { (Tank Return) }\end{array}$ \\
\hline \multicolumn{2}{|c|}{ TK-106-AP Transfer Route to Alternate Receiver Tank } \\
\hline 241-AP-06A Pump Pit & $\begin{array}{c}\text { Transfer Pump through Rigid Jumper to } \\
\text { Nozzle A to Line SN } 616\end{array}$ \\
\hline 241-AP Valve Pit & $\begin{array}{l}\text { Nozzle } 21 \text { through to Nozzle } 17 \text { via } D, C \\
\text { N,P } M, \& H \text { to Line SN } 613\end{array}$ \\
\hline 241-AP-03A Pump Pit & $\begin{array}{l}\text { Nozzle A through Rigid jumper to Nozzle E } \\
\text { (Tank Return) }\end{array}$ \\
\hline \multicolumn{2}{|c|}{ TK-107-AP Transfer Route to Alternate Receiver Tank } \\
\hline 241-AP-07A Pump Pit & $\begin{array}{l}\text { Transfer Pump through Rigid Jumper to } \\
\text { Nozzle A to Line SN } 617\end{array}$ \\
\hline 241-AP Valve Pit & $\begin{array}{c}\text { Nozzle } 23 \text { through to Nozzle } 17 \text { via K, D, } \\
\text { C, N } P, M, \& H \text { to Line SN } 613\end{array}$ \\
\hline 241-AP-03A Pump Pit & Nozzle A through Rigid jumper to Nozzle $\mathrm{E}$ \\
\hline
\end{tabular}




\begin{tabular}{|c|c|}
\hline \multicolumn{2}{|c|}{ (Tank Return) } \\
\hline TK-108-AP Transfer Route to Alternate Receiver Tank \\
\hline 241-AP-08A Pump Pit & $\begin{array}{r}\text { Transfer Pump through Rigid Jumper to } \\
\text { Nozzle A to Line SN 618 }\end{array}$ \\
\hline 241-AP Valve Pit & $\begin{array}{c}\text { Nozzle 22 through to Nozzle 17 via K, D, } \\
\mathrm{C}, \mathrm{N}, \mathrm{P}, \mathrm{M}, \text { \& H to Line SN 613 }\end{array}$ \\
\hline 241-AP-03A Pump Pit & $\begin{array}{c}\text { Nozzle A through Rigid jumper to Nozzle E } \\
\text { (Tank Return) }\end{array}$ \\
\hline
\end{tabular}

\section{TRANSFER ROUTES from 241-AW PRIMARY TANKS TO DESIGNATED RECEIVER TANK 241-AP-104}

\begin{tabular}{|c|c|}
\hline \multicolumn{2}{|c|}{ TK-101-AW Transfer Route to Designated Receiver Tank } \\
\hline 241-AW-01A Pump Pit & $\begin{array}{l}\text { Pump Nozzle through Flex /Rigid Jumper } \\
\text { to Nozzle A to Line SN } 261\end{array}$ \\
\hline 214-AW-A Valve Pit & $\begin{array}{l}\text { Nozzle L16 through Rigid /Flex Jumper to } \\
\text { Nozzle L1 via D to Line SN } 267\end{array}$ \\
\hline TK-102-AW-02A Pump Pit & $\begin{array}{l}\text { Nozzle J through Rigid Jumper to Nozzle } \\
\qquad \text { to Line SN } 609\end{array}$ \\
\hline 241-AP Valve Pit & $\begin{array}{c}\text { Nozzle } 14 \text { through Rigid Jumper to Nozzle } \\
20 \text { via } P, M, H, \& \text { to Line SN } 614\end{array}$ \\
\hline 241-AP-04A Pump Pit & $\begin{array}{c}\text { Nozzle A through Rigid Jumper to Nozzle } \\
\text { E (Tank Return) }\end{array}$ \\
\hline \multicolumn{2}{|c|}{ TK-102-AW Transfer Route to Designated Receiver Tank } \\
\hline 241-AW-02E Pump Pit & $\begin{array}{l}\text { Pump Nozzle through Rigid Jumper to } \\
\text { Nozzle D to Line SN } 272\end{array}$ \\
\hline 241-AW-02A Central Pump Pit & $\begin{array}{l}\text { Nozzle K through Flex Jumper } \\
\text { to Nozzle } V \text { to Line SN } 609\end{array}$ \\
\hline 241-AP Valve Pit & $\begin{array}{c}\text { Nozzle } 14 \text { through Rigid Jumper to Nozzle } \\
20 \text { via } P, M, H, \& J \text { to Line SN } 614\end{array}$ \\
\hline 241-AP-04A Pump Pit & $\begin{array}{c}\text { Nozzle A through Rigid Jumper to Nozzle } \\
\text { E (Tank Return) }\end{array}$ \\
\hline \multicolumn{2}{|c|}{ TK-103-AW Transfer Route to Designated Receiver Tank } \\
\hline 241-AW-03A Central Pump Pit & $\begin{array}{l}\text { Pump Nozzle through Rigid Jumper to } \\
\text { Nozzle A to Line SN } 263\end{array}$ \\
\hline 214-AW-A VALVE PIT & $\begin{array}{l}\text { Nozzle L14 through Rigid Jumper to } \\
\text { Nozzle L1 via D to Line SN } 267\end{array}$ \\
\hline 214-AW-02A Central Pump Pit & 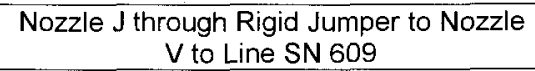 \\
\hline 241-AP Valve Pit & $\begin{array}{c}\text { Nozzle } 14 \text { through Rigid Jumper to Nozzle } \\
20 \text { via } P, M, H, \& \text { to Line SN } 614\end{array}$ \\
\hline 241-AP-04 Central Pump Pit & $\begin{array}{c}\text { Nozzle A through Rigid Jumper to Nozzle } \\
\text { E (Tank Return) }\end{array}$ \\
\hline
\end{tabular}


HNF-3484 Rev. 1

APPENDIX A

\begin{tabular}{|c|c|}
\hline \multicolumn{2}{|c|}{ TK-104-AW Transfer Route to Designated Receiver Tank } \\
\hline 241-AW-04A Pump Pit & $\begin{array}{l}\text { Pump Nozzle through Rigid Jumper to } \\
\text { Nozzle A to Line SN } 264\end{array}$ \\
\hline 214-AW-B Valve Pit & $\begin{array}{l}\text { Nozzle R-14 through Rigid Jumper to } \\
\text { Nozzle R1 via D to Line SN } 268\end{array}$ \\
\hline 241-AW-02A Pump Pit & $\begin{array}{c}\text { Nozzle } \mathrm{H} \text { through Rigid Jumper to Nozzle } \\
\text { U to Line SN } 610\end{array}$ \\
\hline 241-AP Valve Pit & $\begin{array}{l}\text { Nozzle } 13 \text { through Rigid Jumper to Nozzle } \\
20 \text { via N,P, M, H \& J to Line SN } 614\end{array}$ \\
\hline 241-AP-04A Pump Pit & $\begin{array}{c}\text { Nozzle A through Rigid Jumper to Nozzle } \\
\text { E (Tank Return) }\end{array}$ \\
\hline \multicolumn{2}{|c|}{ TK-105-AW Transfer Route to Designated Receiver Tank } \\
\hline 241-AW-05A Pump Pit & $\begin{array}{l}\text { Pump Nozzle through Rigid Jumper to } \\
\text { Nozzle A and Line SN } 265\end{array}$ \\
\hline 214-AW-A Valve Pit & $\begin{array}{l}\text { Nozzle L15 through Rigid Jumper to } \\
\text { Nozzle L1 to Line SN } 267\end{array}$ \\
\hline 214-AW-02A Central Pump Pit & $\begin{array}{c}\text { Nozzle J through Rigid Jumper to Nozzle } \\
\text { V to Line SN } 609\end{array}$ \\
\hline 241-AP Valve Pit & $\begin{array}{l}\text { Nozzle } 14 \text { through Rigid Jumper to Nozzle } \\
20 \text { via } P, M, H, \& \text { J to Line SN614 }\end{array}$ \\
\hline 241-AP-04 Central Pump Pit & $\begin{array}{c}\text { Nozzle A through Rigid Jumper to Nozzle } \\
\text { E (Tank Return) }\end{array}$ \\
\hline \multicolumn{2}{|c|}{ TK-106-AW Transfer Route to Designated Receiver Tank } \\
\hline 241-AW-06A Pump Pit & $\begin{array}{l}\text { Pump Nozzle through Rigid Jumper to } \\
\text { Nozzle A to Line SN } 266\end{array}$ \\
\hline 214-AW-B VALVE PIT & $\begin{array}{l}\text { Nozzle R-15 through Rigid Jumper to } \\
\text { Nozzle R-1 via D to Line SN } 268\end{array}$ \\
\hline 214-AW-02A Central Pump Pit & $\begin{array}{c}\text { Nozzle } H \text { through Rigid Jumper to Nozzle } \\
\qquad U \text { to Line SN } 610\end{array}$ \\
\hline 241-AP Valve Pit & $\begin{array}{c}\text { Nozzle } 13 \text { through Rigid Jumper to Nozzle } \\
20 \text { via N,P, M, H, \& J to Line SN614 }\end{array}$ \\
\hline 241-AP-04 Central Pump Pit & $\begin{array}{c}\text { Nozzle A through Rigid Jumper to Nozzle } \\
\text { E (Tank Return) }\end{array}$ \\
\hline
\end{tabular}


HNF-3484 Rev. 1

APPENDIX A

TRANSFER ROUTES from 241-AW PRIMARY TANKS

TO ALTERNATE RECEIVER TANK 241-AP-103

\begin{tabular}{|c|c|}
\hline \multicolumn{2}{|c|}{ TK-101-AW Transfer Route to Alternate Receiver Tank } \\
\hline 241-AW-01A Pump Pit & $\begin{array}{l}\text { Pump Nozzle through Flex /Rigid Jumper } \\
\text { to Nozzle A and SN } 261\end{array}$ \\
\hline 214-AW-A Valve Pit & $\begin{array}{l}\text { Nozzle L16 through Rigid /Flex Jumper to } \\
\text { Nozzle L1 via D to Line SN } 267\end{array}$ \\
\hline TK-102-AW-02A Pump Pit & $\begin{array}{l}\text { Nozzle J through Rigid Jumper to Nozzle } \\
\qquad \text { to Line SN } 609\end{array}$ \\
\hline 241-AP Vaive Pit & $\begin{array}{c}\text { Nozzle } 14 \text { through Rigid Jumper to Nozzle } \\
17 \text { via } P, M, \& H \text { to Line SN } 613\end{array}$ \\
\hline 241-AP-03A Pump Pit & $\begin{array}{c}\text { Nozzle A through Rigid Jumper to Nozzle } \\
\text { E (Tank Return) }\end{array}$ \\
\hline \multicolumn{2}{|c|}{ TK-102-AW Transfer Route to Alternate Receiver Tank } \\
\hline 241-AW-02E Pump Pit & $\begin{array}{l}\text { Pump Nozzle through Rigid Jumper to } \\
\text { Nozzle D to Line SN } 272\end{array}$ \\
\hline 241-AW-02A Central Pump Pit & $\begin{array}{c}\text { Nozzle K through Flex Jumper to } \\
\text { Nozzle } V \text { to Line SN } 609\end{array}$ \\
\hline 241-AP Valve Pit & $\begin{array}{c}\text { Nozzle } 14 \text { through Rigid Jumper to Nozzle } \\
17 \text { via } P, M, \& H \text { to Line SN } 613\end{array}$ \\
\hline 241-AP-03A Pump Pit & $\begin{array}{c}\text { Nozzle A through Rigid Jumper to Nozzle } \\
\text { E (Tank Return) }\end{array}$ \\
\hline \multicolumn{2}{|c|}{ TK-103-AW Transfer Route to Alternate Receiver Tank } \\
\hline 241-AW-03A Central Pump Pit & $\begin{array}{l}\text { Pump Nozzle through Rigid Jumper to } \\
\text { Nozzle A to Line SN } 263\end{array}$ \\
\hline 214-AW-A VALVE PIT & $\begin{array}{l}\text { Nozzle L14 through Rigid Jumper to } \\
\text { Nozzle L1 via D to Line SN } 267\end{array}$ \\
\hline 214-AW-02A Central Pump Pit & $\begin{array}{c}\text { Nozzle } J \text { through Rigid Jumper to Nozzle } \\
\qquad \text { to Line SN } 609\end{array}$ \\
\hline 241-AP Valve Pit & $\begin{array}{l}\text { Nozzle } 14 \text { through Rigid Jumper to Nozzle } \\
17 \text { via } P, M, \& H \text { to Line SN } 613\end{array}$ \\
\hline 241-AP-03 Central Pump Pit & $\begin{array}{c}\text { Nozzle A through Rigid Jumper to Nozzle } \\
\text { E (Tank Return) }\end{array}$ \\
\hline \multicolumn{2}{|c|}{ TK-104-AW Transfer Route to Alternate Receiver Tank } \\
\hline 241-AW-04A Pump Pit & $\begin{array}{l}\text { Pump Nozzle through Rigid Jumper to } \\
\text { Nozzle A to Line SN } 264\end{array}$ \\
\hline 214-AW-B Valve Pit & $\begin{array}{l}\text { Nozzle R-14 through Rigid Jumper to } \\
\text { Nozzle R1 via D to Line SN } 268\end{array}$ \\
\hline 241-AW-02A Pump Pit & $\begin{array}{l}\text { Nozzle } H \text { through Rigid Jumper to Nozzle } \\
\qquad \text { to Line SN } 610\end{array}$ \\
\hline 241-AP Valve Pit & $\begin{array}{c}\text { Nozzle } 13 \text { through Rigid Jumper to Nozzle } \\
17 \text { via } N, P, M, \& \text { to Line SN } 613\end{array}$ \\
\hline 241-AP-03A Pump Pit & $\begin{array}{c}\text { Nozzle A through Rigid Jumper to Nozzle } \\
\text { E (Tank Return) }\end{array}$ \\
\hline
\end{tabular}




\begin{tabular}{|c|c|}
\hline \multicolumn{2}{|c|}{ TK-105-AW Transfer Route to Alternate Receiver Tank } \\
\hline 241-AW-05A Pump Pit & $\begin{array}{c}\text { Pump Nozzle through Rigid Jumper to } \\
\text { Nozzle A and Line SN 265 }\end{array}$ \\
\hline $214-A W-A$ Valve Pit & $\begin{array}{c}\text { Nozzle L15 through Rigid Jumper to } \\
\text { Nozzle L1 to Line SN 267 }\end{array}$ \\
\hline $214-$ AW-02A Central Pump Pit & $\begin{array}{c}\text { Nozzle J through Rigid Jumper to Nozzle } \\
\text { V to Line SN 609 }\end{array}$ \\
\hline 241-AP Valve Pit & $\begin{array}{c}\text { Nozzle 14 through Rigid Jumper to Nozzle } \\
17 \text { via P, M, \& H to Line SN613 }\end{array}$ \\
\hline 241-AP-03 Central Pump Pit & $\begin{array}{c}\text { Nozzle A through Rigid Jumper to Nozzle } \\
\text { E (Tank Return) }\end{array}$ \\
\hline TK-106-AW Transfer Route to Alternate Receiver Tank \\
\hline 241-AW-06A Pump Pit & $\begin{array}{c}\text { Pump Nozzle through Rigid Jumper to } \\
\text { Nozzle A to Line SN 266 }\end{array}$ \\
\hline 214-AW-B VALVE PIT & $\begin{array}{c}\text { Nozzle R-15 through Rigid Jumper to } \\
\text { Nozzle R-1 via D to Line SN 268 }\end{array}$ \\
\hline 214-AW-02A Central Pump Pit & $\begin{array}{c}\text { Nozzle H through Rigid Jumper to Nozzle } \\
\text { U to Line SN 610 }\end{array}$ \\
\hline 241-AP Valve Pit & $\begin{array}{c}\text { Nozzle 13 through Rigid Jumper to Nozzle } \\
17 \text { via N, P, M, \& H to Line SN613 }\end{array}$ \\
\hline 241-AP-03 Central Pump Pit & $\begin{array}{c}\text { Nozzle A through Rigid Jumper to Nozzle } \\
\text { E (Tank Return) }\end{array}$ \\
\hline
\end{tabular}

\section{TRANSFER ROUTES from 241-AY PRIMARY TANKS TO DESIGNATED RECEIVER TANK 241-AP-104}

\begin{tabular}{|c|c|}
\hline \multicolumn{2}{|c|}{ TK-101-AY Transfer Route to Designated Receiver Tank } \\
\hline $241-A Y-01 D$ Pump Pit & $\begin{array}{c}\text { Pump Nozzle through Flex Jumper to } \\
\text { Nozzle U2 to Line SL 504 }\end{array}$ \\
\hline $241-A Y-02 A$ Pump Pit & $\begin{array}{c}\text { Nozzle U8 through Rigid Jumper to Nozzle } \\
\text { U3 to Line SL 503 }\end{array}$ \\
\hline $241-A Y-02 D$ Pump Pit & $\begin{array}{c}\text { Nozzle U2 through Rigid Jumper to Nozzle } \\
\text { U3 to Line SL 502 }\end{array}$ \\
\hline $241-A X-B$ Valve Pit & $\begin{array}{c}\text { Nozzle R16 through Flex Jumper to } \\
\text { Nozzle R1 to Line SN 213/200 }\end{array}$ \\
\hline $241-A-B$ Valve Pit & $\begin{array}{c}\text { Nozzle R1 through Rigid Jumper to Nozzle } \\
\text { R19 to Line SN 204 }\end{array}$ \\
\hline 241-A-A Valve Pit & $\begin{array}{c}\text { Nozzle L19 through Rigid Jumper to } \\
\text { Nozzle L2 to Line SN 220 }\end{array}$ \\
\hline 241-AW-A Valve Pit & $\begin{array}{c}\text { Nozzle L2 through Flex/Rigid Jumper to } \\
\text { Nozzle L1 via D to Line SN 267 }\end{array}$ \\
\hline 241-AW-02A Pump Pit & $\begin{array}{c}\text { Nozzle J through Rigid Jumper to Nozzle } \\
\text { V to Line SN 609 }\end{array}$ \\
\hline
\end{tabular}


HNF-3484 Rev. 1

APPENDIX A

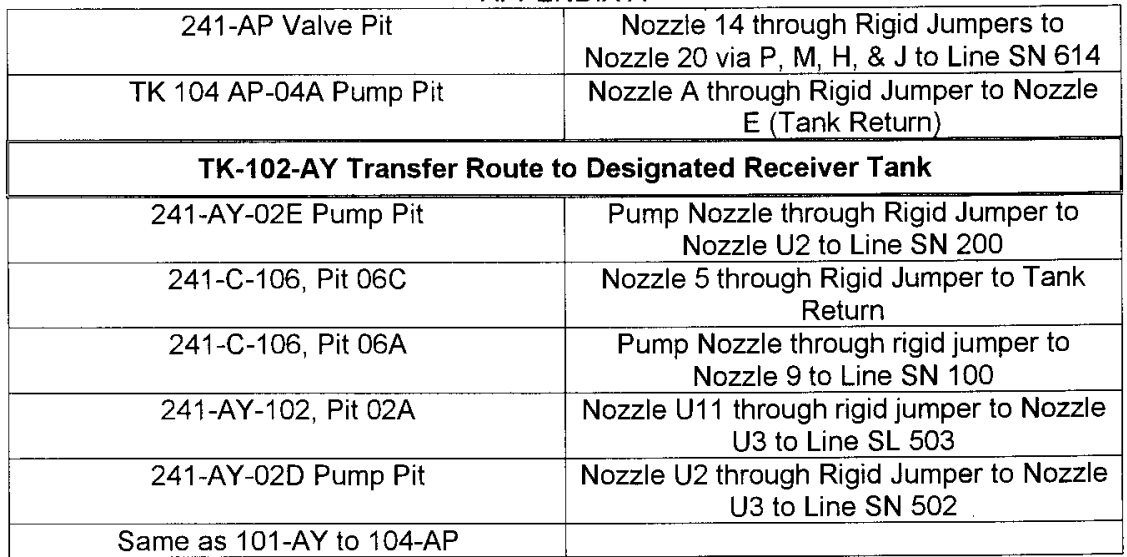

\section{TRANSFER ROUTES from 241-AY PRIMARY TANKS TO ALTERNATE RECEIVER TANK 241-AP-103}

\begin{tabular}{|c|c|}
\hline \multicolumn{2}{|c|}{ TK-101-AY Transfer Route to Alternate Receiver Tank } \\
\hline 241-AY-01D Pump Pit & $\begin{array}{c}\text { Pump Nozzle through Flex Jumper to } \\
\text { Nozzle U2 to Line SL 504 }\end{array}$ \\
\hline 214-AY-02A Pump Pit & $\begin{array}{c}\text { Nozzle U8 through Rigid Jumper to Nozzle } \\
\text { U3 to Line SL 503 }\end{array}$ \\
\hline 241-AY-02D Pump Pit & $\begin{array}{c}\text { Nozzle U2 through Rigid Jumper to Nozzle } \\
\text { U3 to Line SL 502 }\end{array}$ \\
\hline 241-AX-B Valve Pit & $\begin{array}{c}\text { Nozzle R16 through Flex Jumper to } \\
\text { Nozzle R1 to Line SN 213/200 }\end{array}$ \\
\hline 241-A-B Valve Pit & $\begin{array}{c}\text { Nozzle R1 through Rigid Jumper to Nozzle } \\
\text { R19 to Line SN 204 }\end{array}$ \\
\hline 241-A-A Valve Pit & $\begin{array}{c}\text { Nozzle L19 through Rigid Jumper to } \\
\text { Nozzle L2 to Line SN 220 }\end{array}$ \\
\hline 241-AW-A Valve Pit & $\begin{array}{c}\text { Nozzle L2 through Flex/Rigid Jumper to } \\
\text { Nozzle L1 via D to Line SN 267 }\end{array}$ \\
\hline 241-AW-02A Pump Pit & $\begin{array}{c}\text { Nozzle J through Rigid Jumper to Nozzle } \\
\text { V to Line SN 609 }\end{array}$ \\
\hline 241-AP Valve Pit & $\begin{array}{c}\text { Nozzle 14 through Rigid Jumpers to } \\
\text { Nozzle 17 via P, M, \& H to Line SN 613 }\end{array}$ \\
\hline TK 104 AP-03A Pump Pit & $\begin{array}{c}\text { Nozzle A through Rigid Jumper to Nozzle } \\
\text { E (Tank Return) }\end{array}$ \\
\hline TK-102-AY Transfer Route to Alternate Receiver Tank \\
\hline 241-AY-02E Pump Pit & $\begin{array}{c}\text { Pump Nozzle through Rigid Jumper to } \\
\text { Nozzle U2 to Line SN 200 }\end{array}$ \\
\hline \hline
\end{tabular}




\begin{tabular}{|c|c|}
\hline 241-C-106, Pit 06C & $\begin{array}{c}\text { Nozzle 5 through Rigid Jumper to Tank } \\
\text { Return }\end{array}$ \\
\hline 241-C-106, Pit 06A & $\begin{array}{c}\text { Pump Nozzle through rigid jumper to } \\
\text { Nozzle 9 to Line SN 100 }\end{array}$ \\
\hline 241-AY-102, Pit 02A & $\begin{array}{c}\text { Nozzle U11 through rigid jumper to Nozzle } \\
\text { U3 to Line SL 503 }\end{array}$ \\
\hline 241-AY-02D Pump Pit & $\begin{array}{c}\text { Nozzle U2 through Rigid Jumper to Nozzle } \\
\text { U3 to Line SN 502 }\end{array}$ \\
\hline Same as 101-AY to 103-AP & \\
\hline
\end{tabular}

\section{TRANSFER ROUTES from 241-AZ PRIMARY TANKS TO DESIGNATED RECEIVER TANK 241-AP-104}

\begin{tabular}{|c|c|}
\hline \multicolumn{2}{|c|}{ TK-101-AZ Transfer Route to Designated Receiver Tank } \\
\hline 241-AZ-01C Pump Pit & $\begin{array}{c}\text { Pump Nozzle through Flex Jumper to } \\
\text { Nozzle U6 to Line SN 601 }\end{array}$ \\
\hline $214-A Z-02 B$ Pump Pit & $\begin{array}{c}\text { Nozzle U6 through Flex Jumper to Nozzle } \\
\text { U5 to Line SN } 600\end{array}$ \\
\hline $241-A X-A$ Valve Pit & $\begin{array}{c}\text { Nozzle L16 through Flex Jumper to Nozzle } \\
\text { L19 to Line SN 210 }\end{array}$ \\
\hline 241-AX-B Valve Pit & $\begin{array}{c}\text { Nozzle R19 through Flex Jumper to } \\
\text { Nozzle R16 to Line SL 502 }\end{array}$ \\
\hline 241-AY-02D Pump Pit & $\begin{array}{c}\text { Nozzle U3 through Rigid Jumper to Nozzle } \\
\text { U2 to Line SL 503 }\end{array}$ \\
\hline 241-AY-02A Pump Pit & $\begin{array}{c}\text { Nozzle U3 through Rigid Jumper to Nozzle } \\
\text { U8 to Line SL 504 }\end{array}$ \\
\hline 241-AY-01D & $\begin{array}{c}\text { Nozzle U2 through Flex Jumper to the } \\
\text { Tank Return Nozzle }\end{array}$ \\
\hline TK-102-AZ Transfer Route to Designated Receiver Tank \\
\hline 241-AZ-02B Pump Pit & $\begin{array}{c}\text { Pump Nozzle through Flex Jumper to } \\
\text { Nozzle U5 to Line SN 600 }\end{array}$ \\
\hline 241-AX-A Valve Pit & $\begin{array}{c}\text { Nozzle L16 through Flex Jumper to Nozzle } \\
\text { L19 to Line SN 210 }\end{array}$ \\
\hline 241-AX-B Valve Pit & $\begin{array}{c}\text { Nozzle R19 through Flex Jumper to } \\
\text { Nozzle R16 to Line SL 502 }\end{array}$ \\
\hline 241-AY-02D Pump Pit & $\begin{array}{c}\text { Nozzle U3 through Rigid Jumper to Nozzle } \\
\text { U2 to Line SL 503 }\end{array}$ \\
\hline 241-AY-02A Pump Pit & $\begin{array}{c}\text { Nozzle U3 through Rigid Jumper to Nozzle } \\
\text { U8 to Line SL 504 }\end{array}$ \\
\hline 241-AY-01D & $\begin{array}{c}\text { Nozzle U2 through Flex Jumper to the } \\
\text { Tank Return Nozzle }\end{array}$ \\
\hline
\end{tabular}




\section{TRANSFER ROUTES from 241-AZ PRIMARY TANKS TO ALTERNATE RECEIVER TANK 241-AP-103}

\begin{tabular}{|c|c|}
\hline \multicolumn{2}{|c|}{ TK-101-AZ Transfer Route to Alternate Receiver Tank } \\
\hline 241-AZ-01C Pump Pit & $\begin{array}{c}\text { Pump Nozzle through Flex Jumper to } \\
\text { Nozzle U6 to Line SN 601 }\end{array}$ \\
\hline 214-AZ-02B Pump Pit & $\begin{array}{c}\text { Nozzle U6 through Flex Jumper to Nozzle } \\
\text { U5 to Line SN 600 }\end{array}$ \\
\hline 241-AX-A Valve Pit & $\begin{array}{c}\text { Nozzle L16 through Flex Jumper to Nozzle } \\
\text { L19 to Line SN 210 }\end{array}$ \\
\hline 241-AX-B Valve Pit & $\begin{array}{c}\text { Nozzle R19 through Flex Jumper to } \\
\text { Nozzle R16 to Line SL 502 }\end{array}$ \\
\hline 241-AY-02D Pump Pit & $\begin{array}{c}\text { Nozzle U3 through Flex Jumper to Tank } \\
\text { Return Nozzle }\end{array}$ \\
\hline TK-102-AZ Transfer Route to Alternate Receiver Tank \\
\hline 241-AZ-02B Pump Pit & $\begin{array}{c}\text { Pump Nozzle through Flex Jumper to } \\
\text { Nozzle U5 to Line SN 600 }\end{array}$ \\
\hline 241-AX-A Valve Pit & $\begin{array}{c}\text { Nozzle L16 through Flex Jumper to Nozzle } \\
\text { L19 to Line SN 210 }\end{array}$ \\
\hline 241-AX-B Valve Pit & $\begin{array}{c}\text { Nozzle R19 through Flex Jumper to } \\
\text { Nozzle R16 to Line SL 502 }\end{array}$ \\
\hline 241-AY-02D Pump Pit & $\begin{array}{c}\text { Nozzle U3 through Flex Jumper to Yank } \\
\text { Return Nozzle }\end{array}$ \\
\hline
\end{tabular}

TRANSFER ROUTES from 241-SY PRIMARY TANKS TO DESIGNATED RECEIVER TANK 241-AP-104

\begin{tabular}{|c|c|}
\hline \multicolumn{2}{|c|}{ TK-101-SY Transfer Route to Designated Receiver Tank } \\
\hline 241-SY-101, 42" Riser \# 007 & $\begin{array}{c}\text { Pump Nozzle through Flex Jumper to Over } \\
\text { Ground Transfer Line }\end{array}$ \\
\hline 214-02A & Flex Jumper to Nozzle E (Tank Return) \\
\hline TK-102-SY Transfer Route to Designated Receiver Tank \\
\hline 241-SY-02A Pump Pit & $\begin{array}{c}\text { Pump Nozzle through Flex Jumper to } \\
\text { Nozzle J to Line SN 285 }\end{array}$ \\
\hline 241-SY-A Valve Pit & $\begin{array}{c}\text { Nozzle L11 through Rigid Jumper to } \\
\text { Nozzle L12 to Line SNL 3150 }\end{array}$ \\
\hline 244-A Lift Station & $\begin{array}{c}\text { Through 6241-A Diversion Box, \& 6241-V } \\
\text { Vent Station to Nozzle P17 through Rigid } \\
\text { Jumper to Nozzle P9 to Line SN 216 }\end{array}$ \\
\hline 241-A-B Valve Pit & $\begin{array}{c}\text { Nozzle R16 through Rigid Jumper to } \\
\text { Nozzle R19 to Line SN 204 }\end{array}$ \\
\hline
\end{tabular}




\begin{tabular}{|c|c|}
\hline 241-A-A Valve Pit & $\begin{array}{l}\text { Nozzle L19 through Rigid/Flex Jumper to } \\
\text { Nozzle L2 to Line SN } 220\end{array}$ \\
\hline 241-AW-A Valve Pit & $\begin{array}{l}\text { Nozzle L2 through Rigid/Flex Jumper to } \\
\text { Nozzle L1 via D to Line SN } 267\end{array}$ \\
\hline 241-AW-02A Pump Pit & $\begin{array}{c}\text { Nozzle J through Rigid Jumper to Nozzle } \\
\qquad \text { to Line SN } 609\end{array}$ \\
\hline 241-AP Valve Pit & $\begin{array}{l}\text { Nozzle } 14 \text { through Rigid Jumper to Nozzle } \\
20 \text { via } \mathrm{P}, \mathrm{M}, \mathrm{H}, \text { \& J to Line SN } 614\end{array}$ \\
\hline 241-AP-04A Pump Pit & $\begin{array}{c}\text { Nozzle A through Rigid Jumper to Nozzle } \\
\text { E (Tank Return) }\end{array}$ \\
\hline \multicolumn{2}{|c|}{ TK-103-SY Transfer Route to Designated Receiver Tank } \\
\hline 241-SY-03A Pump Pit & $\begin{array}{l}\text { Pump Nozzle through Flex Jumper to } \\
\text { Nozzle A to Line SN } 279\end{array}$ \\
\hline 241-SY-B Valve Pit & $\begin{array}{l}\text { Nozzle R14 through Rigid Jumper to } \\
\text { Nozzle R19 to Line SN } 280\end{array}$ \\
\hline 241-A Valve Pit & $\begin{array}{c}\text { Nozzle } 19 \text { through Flex Jumper to Nozzle } \\
\text { L16 via } \mathrm{H} \text { to Line SN } 277\end{array}$ \\
\hline 241-02A Pump Pit & $\begin{array}{c}\text { Nozzle A through Rigid Jumper to Nozzle } \\
\text { G (Tank Return) }\end{array}$ \\
\hline
\end{tabular}

\section{TRANSFER ROUTES from 241-SY PRIMARY TANKS TO ALTERNATE RECEIVER TANK 241-AP-103}

\begin{tabular}{|c|c|}
\hline \multicolumn{2}{|c|}{ TK-101-SY Transfer Route to Alternate Receiver Tank } \\
\hline 241-SY-101, 42" Riser \# 007 & $\begin{array}{c}\text { Pump Nozzle through Flex Jumper to Over } \\
\text { Ground Transfer Line }\end{array}$ \\
\hline 241-02A & Flex Jumper to Nozzle E (Tank Return) \\
\hline TK-102-SY Transfer Route to Alternate Receiver Tank \\
\hline 241-SY-02A Pump Pit & $\begin{array}{c}\text { Pump Nozzle through Flex Jumper to } \\
\text { Nozzle J to Line SN 285 }\end{array}$ \\
\hline 241-SY-A Valve Pit & $\begin{array}{c}\text { Nozzle L11 through Rigid Jumper to } \\
\text { Nozzle L12 to Line SNL 3150 }\end{array}$ \\
\hline 244-A Lift Station & $\begin{array}{c}\text { Through 6241-A Diversion Box, \& 6241-V } \\
\text { Vent Station to Nozzle P17 through Rigid } \\
\text { Jumper to Nozzle P9 to Line SN 216 }\end{array}$ \\
\hline 241-A-B Valve Pit & $\begin{array}{c}\text { Nozzle R16 through Rigid Jumper to } \\
\text { Nozzle R19 to Line SN 204 }\end{array}$ \\
\hline 241-A-A Valve Pit & $\begin{array}{c}\text { Nozzle L19 through Rigid/Flex Jumper to } \\
\text { Nozzle L2 to Line SN 220 }\end{array}$ \\
\hline 241-AW-A Valve Pit & $\begin{array}{c}\text { Nozzle L2 through Rigid/Flex Jumper to } \\
\text { Nozzle L1 via D to Line SN 267 }\end{array}$ \\
\hline 241-AW-02A Pump Pit & $\begin{array}{c}\text { Nozzle J through Rigid Jumper to Nozzle } \\
\text { V to Line SN 609 }\end{array}$ \\
\hline
\end{tabular}


HNF-3484 Rev. 1

APPENDIX A

\begin{tabular}{|c|c|}
\hline 241-AP Valve Pit & $\begin{array}{c}\text { Nozzle 14 through Rigid Jumper to Nozzle } \\
17 \text { via P, M, \& H to Line SN 613 } \\
\text { Nozzle A through Rigid Jumper to Nozzle } \\
\text { E ( Tank Return) }\end{array}$ \\
\hline 241-AP-03A Pump Pit & $\begin{array}{c}\text { Pump Nozzle through Flex Jumper to } \\
\text { Nozzle A to Line SN 279 }\end{array}$ \\
\hline TK-103-SY Transfer Route to Alternate Receiver Tank \\
\hline 241-SY-03A Pump Pit & $\begin{array}{c}\text { Nozzle R14 through Rigid Jumper to } \\
\text { Nozzle R19 to Line SN 280 }\end{array}$ \\
\hline 241-A Valve Pit & $\begin{array}{c}\text { Nozzle 19 through Flex Jumper to Nozzle } \\
\text { L16 via H to Line SN 277 }\end{array}$ \\
\hline 241-02A Pump Pit & $\begin{array}{c}\text { Nozzle A through Rigid Jumper to Nozzle } \\
\text { G ( Tank Return) }\end{array}$ \\
\hline
\end{tabular}


HNF-3484 Rev. 1

APPENDIX B

APPENDIX B

LIST OF IMPLEMENTING PROCEDURES

AND RELEVANT DRAWINGS

B - 1 
HNF-3484 Rev. 1

APPENDIX B

\begin{tabular}{|c|c|c|}
\hline $\begin{array}{l}\text { TANK } \\
\text { FARM }\end{array}$ & $\begin{array}{l}\text { PROCEDURE } \\
\text { NUMBER }\end{array}$ & PROCEDURE TITLE \\
\hline AN & TO-001-181 & Emergency Pumping Procedure for AN-Farm \\
\hline AP & TO-001-182 & Emergency Pumping Procedure for AP-Farm \\
\hline AW & TO-001-183 & Emergency Pumping Procedure for AW-Farm \\
\hline AY & TO-001-188 & Emergency Pumping Procedure for AY-Farm \\
\hline$\overline{A Z}$ & TO-001-189 & Emergency Pumping Procedure for AZ-Farm \\
\hline SY & TO-001-184 & Emergency Pumping Procedure for SY Farm \\
\hline
\end{tabular}




\begin{tabular}{|c|c|c|}
\hline \multicolumn{3}{|c|}{ 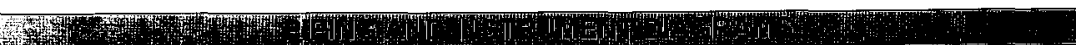 } \\
\hline 4t & $\frac{1}{1+3}+1$ & 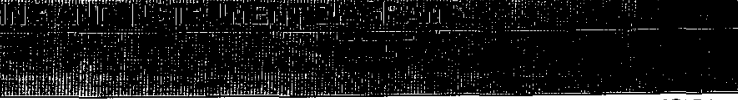 \\
\hline \multirow{3}{*}{ AN } & H 140020501 & $\begin{array}{l}\text { WASTE STORAGE TANK ANNULUS INSTM SYS WSTA } \\
\text { O\&M SYS P\&ID }\end{array}$ \\
\hline & H 140020601 & $\begin{array}{l}\text { WASTE STORAGE TANK INSTM SYSTEM WST O\&MN } \\
\text { SYSTEM P\&ID }\end{array}$ \\
\hline & H 140020801 & WASTE TRANSFER SYSTEM-WT-O\&M SYSTEM P\&ID \\
\hline \multirow{3}{*}{ AP } & H 140020503 & $\begin{array}{l}\text { WASTE STORAGE TANK ANNULUS INSTM SYS WSTA } \\
\text { O\&M SYS P\&ID }\end{array}$ \\
\hline & H 140020603 & $\begin{array}{l}\text { WASTE STARAGE TANK INSTR SYSTEM WST O\&M } \\
\text { SYSTEM P\&ID }\end{array}$ \\
\hline & H 140020803 & WASTE TRANSFER SYSTEM(WT) O\&M SYSTEM P\&ID \\
\hline \multirow{3}{*}{ AW } & H 140020502 & $\begin{array}{l}\text { WASTE STORAGE TANK ANNULUS INSTM SYS WSTA } \\
\text { O\&M SYS P\&ID }\end{array}$ \\
\hline & H 140020602 & $\begin{array}{l}\text { WASTE STORAGE TANK INSTM SYSTEM WST O\&M } \\
\text { SYSTEM P\&ID }\end{array}$ \\
\hline & $\begin{array}{l}H \\
140020803 M\end{array}$ & WASTE TRANSFER SYSTEM-WT-O\&M SYSTEM P\&ID \\
\hline \multirow[t]{2}{*}{$A X$} & H 140020609 & $\begin{array}{l}\text { WASTE STORAGE TANK SYSTEM(WST) O\&M SYSTEM } \\
\text { P\&ID }\end{array}$ \\
\hline & H 140020809 & 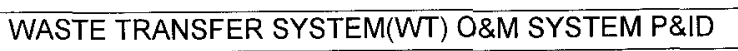 \\
\hline$A Y$ & $\mathrm{H} 020064462$ & P\&ID TANK 241-AY-102 ANNULUS \\
\hline$\overline{A Z}$ & H 140020801 & WASTE TRANSFER SYSTEM(WT) O\&M SYSTEM P\&ID \\
\hline \multirow{3}{*}{ SY } & H 140020531 & $\begin{array}{l}\text { WASTE STORAGE TANK ANNULUS SYSTEM (WSTA) } \\
\text { O\&M SYSTEM P\&ID }\end{array}$ \\
\hline & H 140020631 & $\begin{array}{l}\text { WASTE STORAGE TANK SYSTEM(WST) O\&M SYSTEM } \\
\text { P\&ID }\end{array}$ \\
\hline & H 140020831 & WASTE TRANSFER SYSTEM(WT) O\&M SYSTEM P\&ID \\
\hline
\end{tabular}



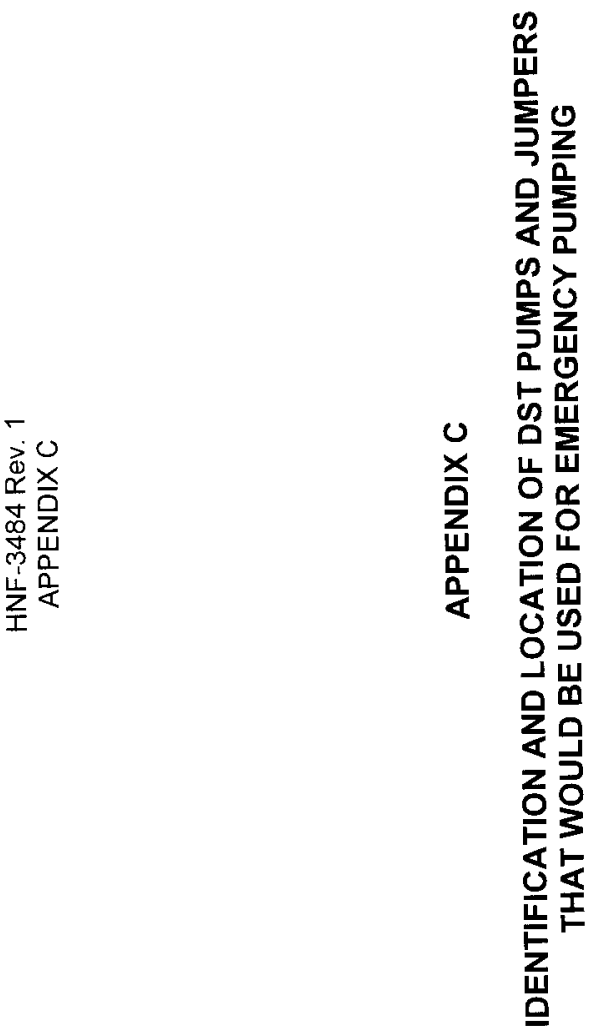


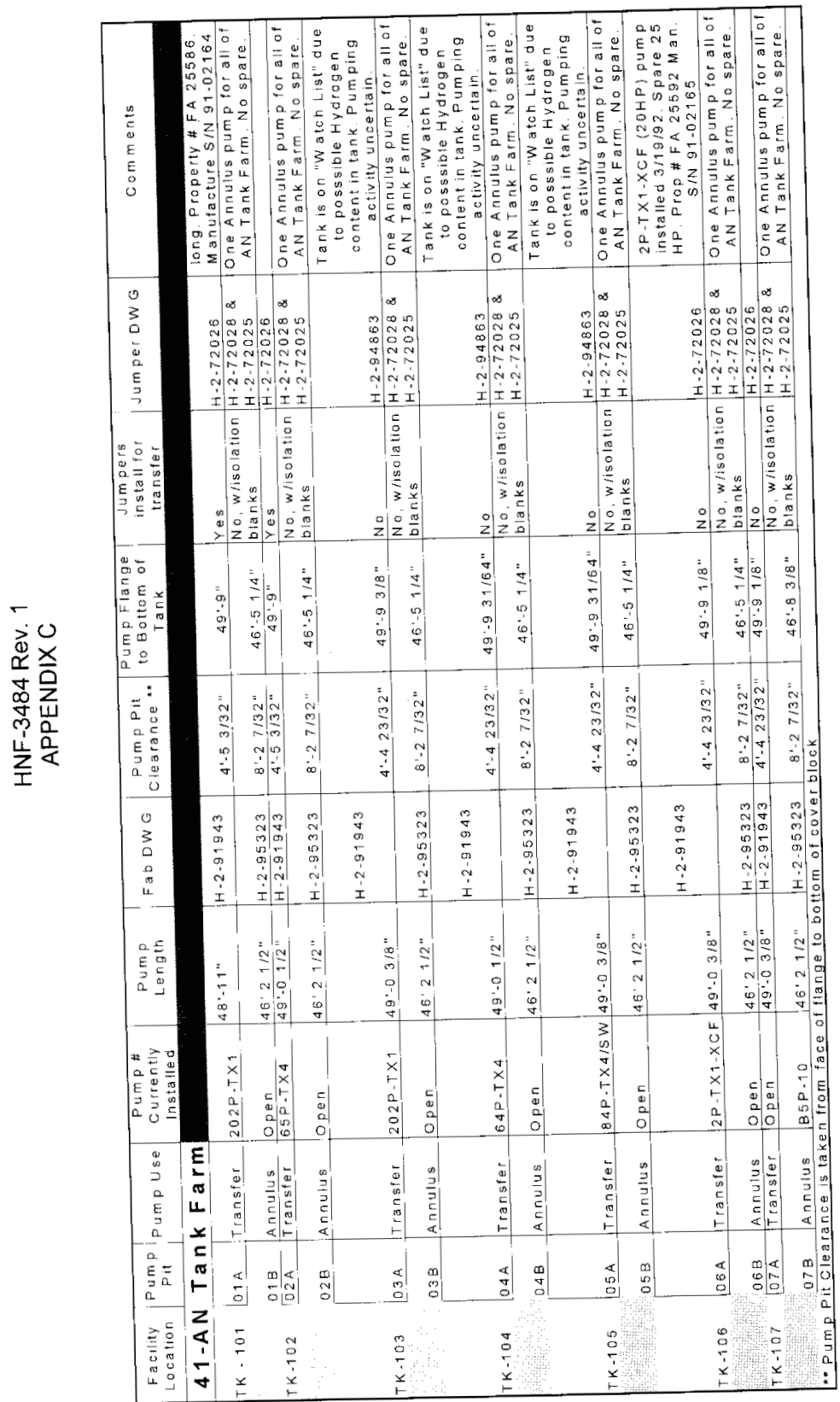

0
1
0 


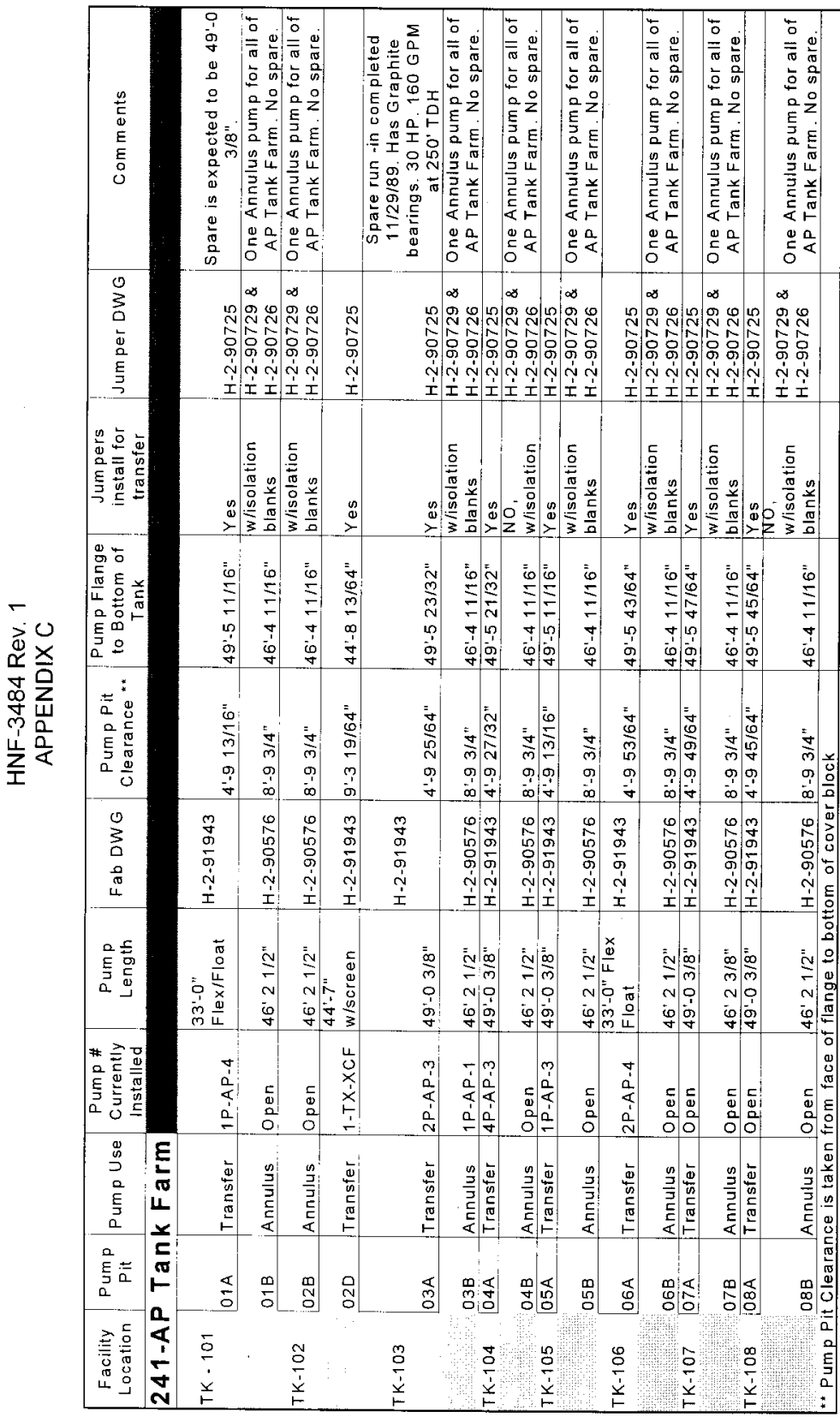




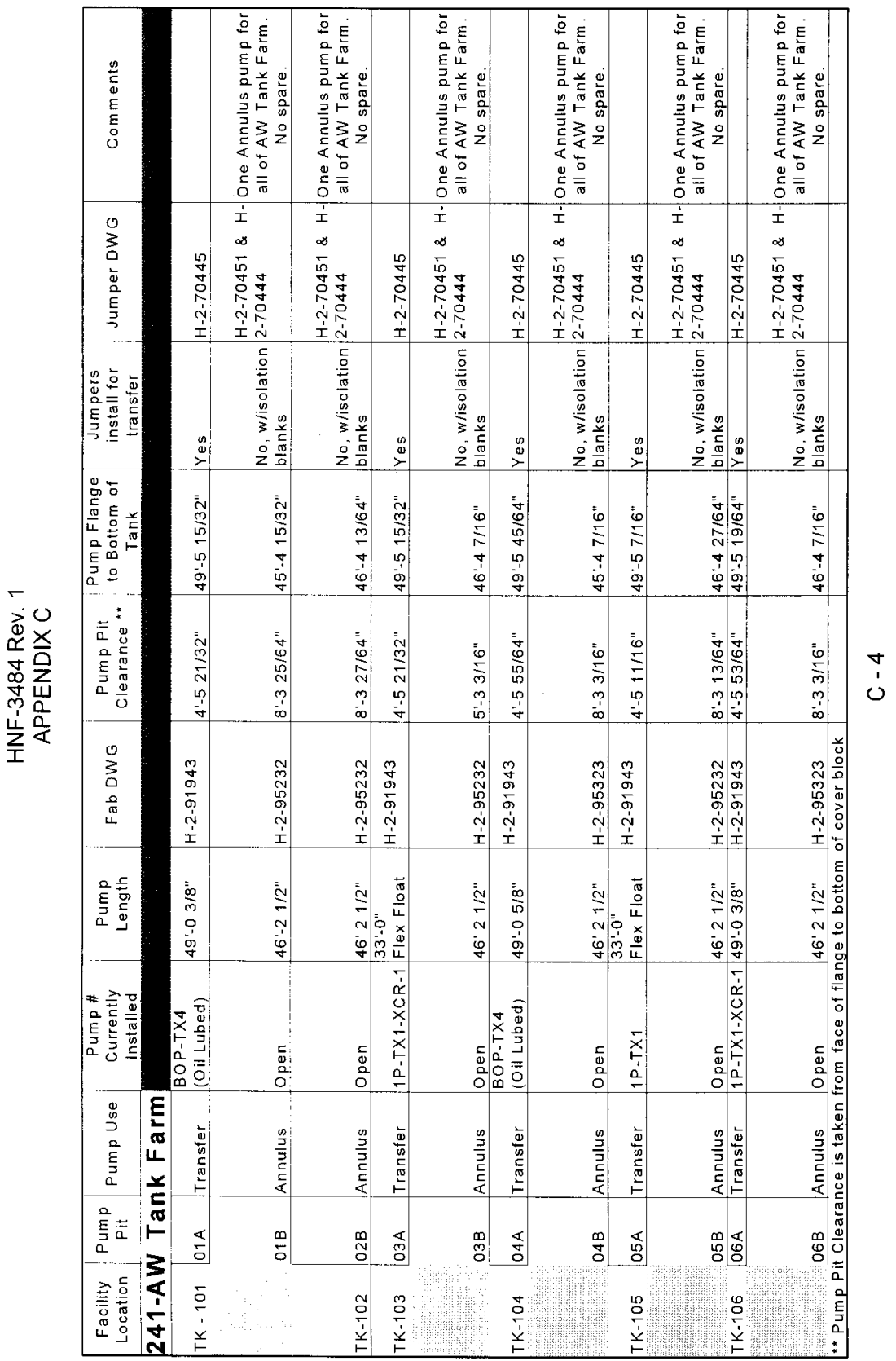




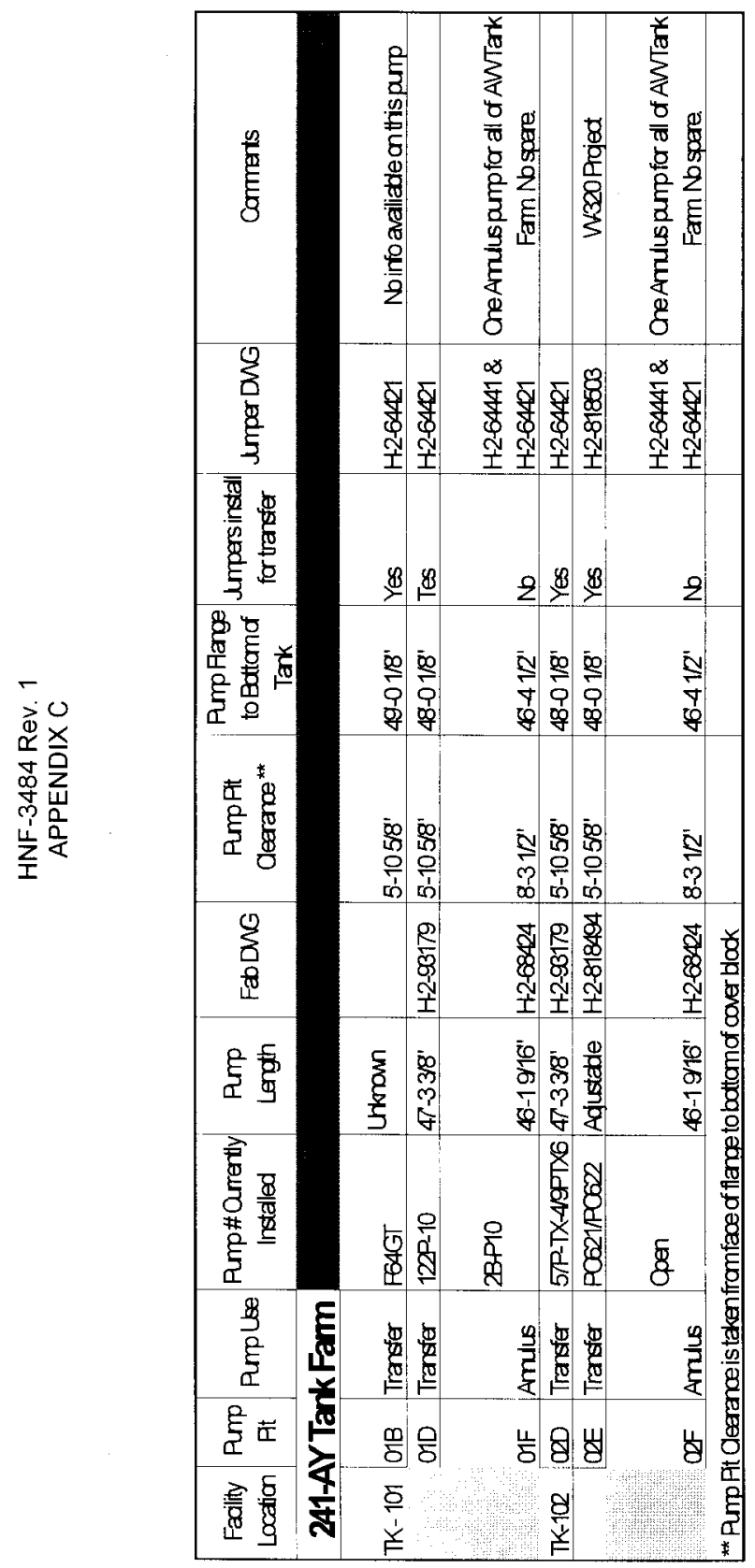




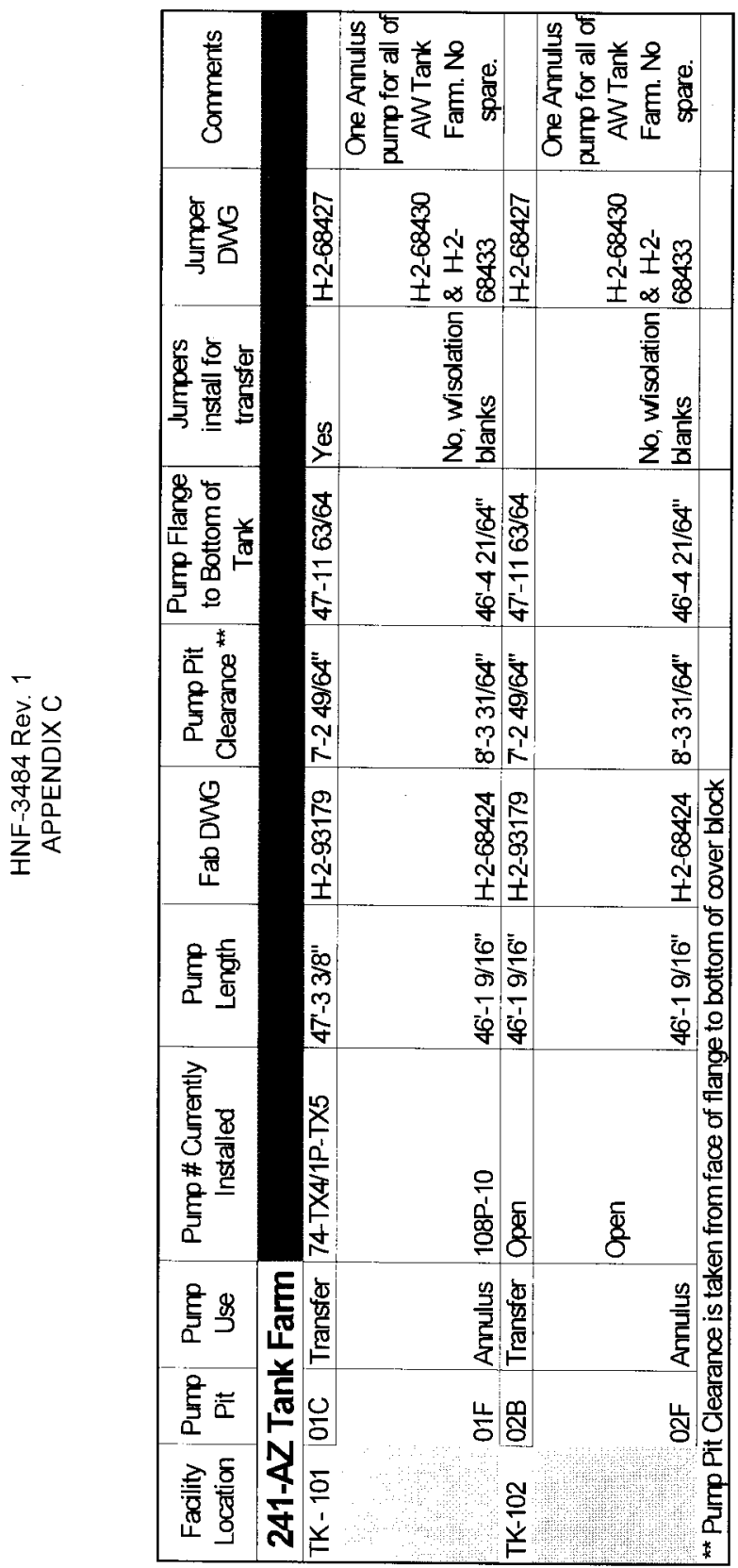

0
0 


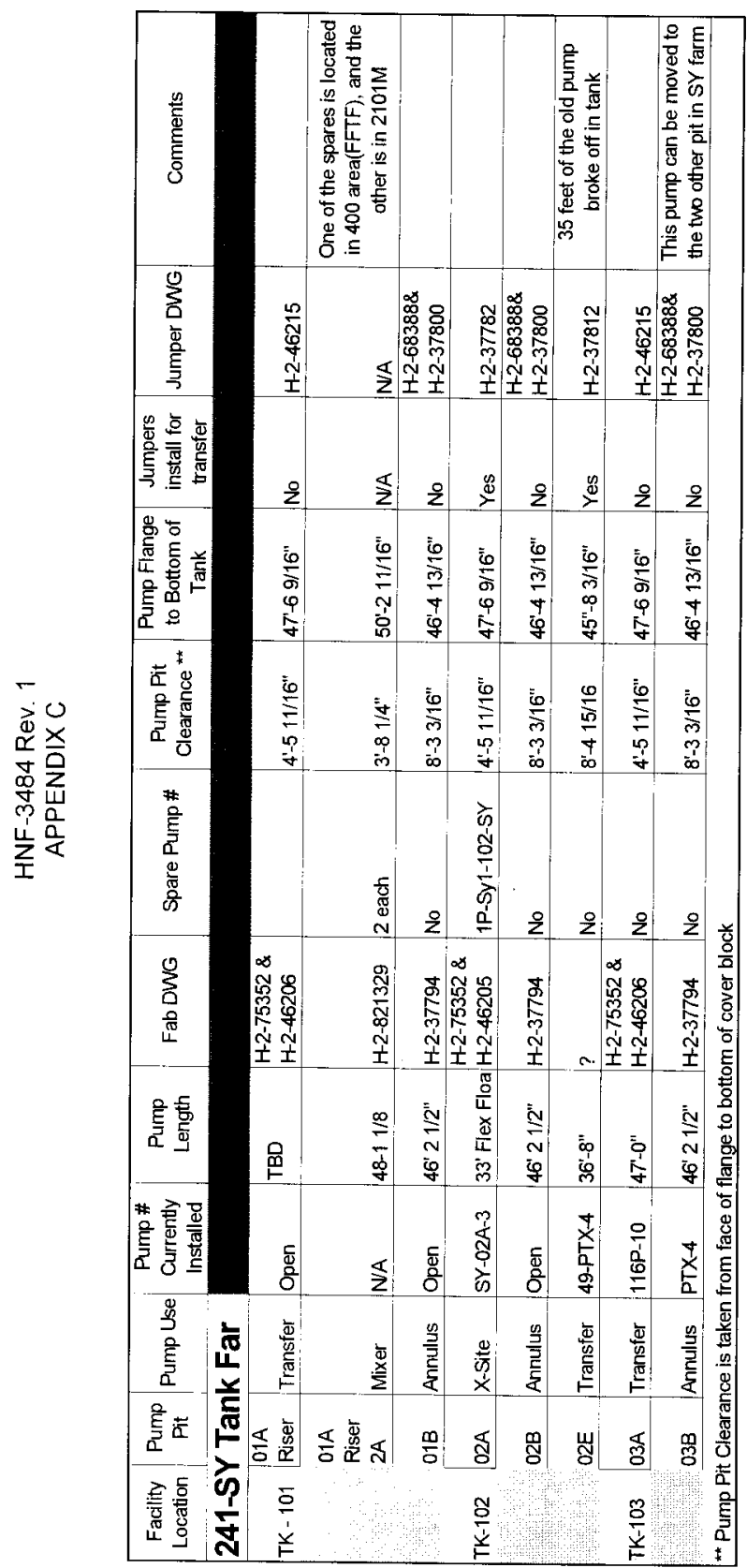


HNF-3484 Rev. 1

APPENDIX D

APPENDIX D

VOLUME OF LIQUID IN ANNULUS OF DOUBLE-SHELL TANK

AT VARIOUS DEPTHS

D - 1 


\section{CROSS-SECTION OF ANNULUS OF DOUBLE-SHELL TANK}

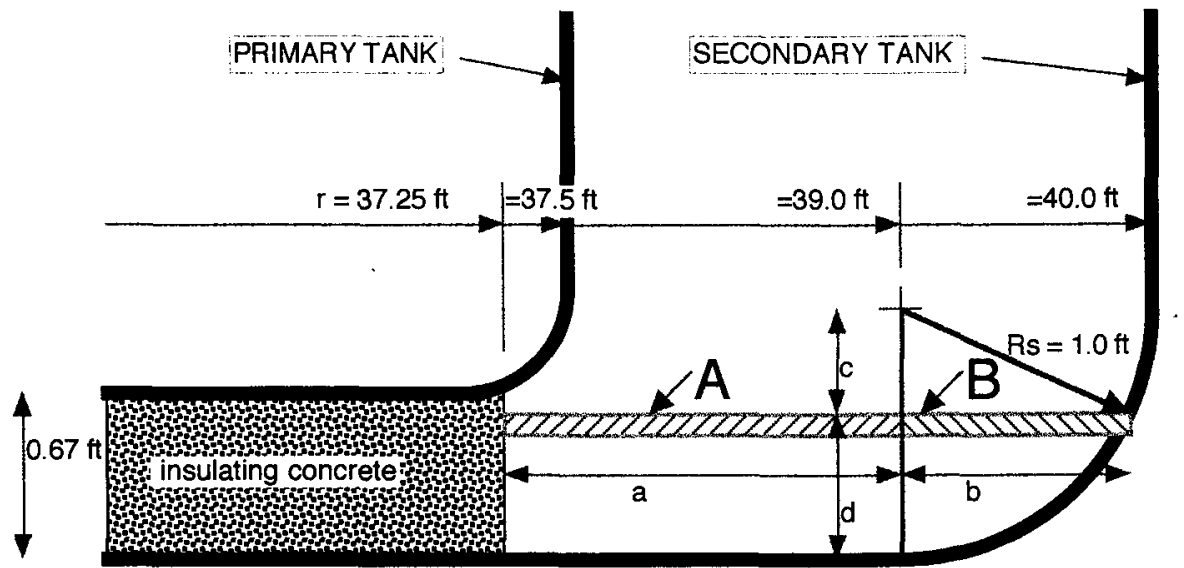

PROBLEM: Calculate volume of liquid in annulus at various depths.

ASSUMPTIONS: Reference drawings $\mathrm{H}-2-37772$, and $\mathrm{H}-2-37705$ are accurate.

Insulating concrete absorbs no liquid. SY-101 is representative of all DSTs.

Volume can be approximated by dividing annulus space into relatively simple geometric forms and calculating the volume of those forms.

Forms $A$ \& $B$ are squat hollow cylinders where Volume $=P i$ height $\left(\right.$ radiuso $^{2}-$ radiusi $^{2}$ ).

$a=1.75 \mathrm{ft}$ from 0 to 8 inches above bottom; $a=1.50 \mathrm{ft}$ above 8 inches above bottom.

$R s^{2}=b^{2}+c^{2} ;$ or $b=$ square root $\left(R s^{2}-c^{2}\right)$

Volume insulating concrete $=\mathrm{Pi}^{*}$ height $\left(\right.$ radius $\left.^{2}\right)=\mathrm{Pi}(0.67)(37.25)^{2}=2,908 \mathrm{ft} 3=21,780$ gal.

Volume per inch in annulus above 12 inches above bottom is constant at $380 \mathrm{gal} / \mathrm{inch}$.

\begin{tabular}{|c|c|c|c|c|c|c|c|c|c|}
\hline & A & B & C & D & $E$ & $F$ & $\mathbf{G}$ & $\mathrm{H}$ & 1 \\
\hline 1 & $d$ (inches) & $a(f t)$ & $c(\mathrm{ft})$ & $b(f t)$ & Vol A (ft3) & $\mathrm{Vol} B(\mathrm{ft} 3)$ & $\mathrm{Jol} A+B(\mathrm{ft} 3$ & Vol (gal) & Vol cum (gal) \\
\hline 2 & 1 & 1.75 & 0.92 & 0.40 & 34.9 & 8.2 & 43 & 323 & $\quad 323$ \\
\hline 3 & 2 & 1.75 & 0.83 & 0.55 & 34.9 & 11.4 & 46 & 347 & 670 \\
\hline 4 & 3 & 1.75 & 0.75 & 0.66 & 34.9 & 13.6 & 49 & 364 & 1,034 \\
\hline 5 & 4 & 1.75 & 0.67 & 0.75 & 34.9 & 15.4 & 50 & 377 & 1,410 \\
\hline 6 & 5 & 1.75 & 0.58 & 0.81 & 34.9 & 16.8 & 52 & 387 & 1,797 \\
\hline 7 & 6 & 1.75 & 0.50 & 0.87 & 34.9 & 17.9 & 53 & 396 & 2,193 \\
\hline 8 & 7 & 1.75 & 0.42 & 0.91 & 34.9 & 18.8 & 54 & 402 & 2,595 \\
\hline 9 & 8 & 1.75 & 0.33 & 0.94 & 34.9 & 19.5 & 54 & 408 & 3,003 \\
\hline 10 & 9 & 1.50 & 0.25 & 0.97 & 30.0 & 20.0 & 50 & 375 & 3,378 \\
\hline 11 & 10 & 1.50 & 0.17 & 0.99 & 30.0 & 20.4 & 50 & 378 & 3,756 \\
\hline 12 & 11 & 1.50 & 0.08 & 1.00 & 30.0 & 20.6 & 51 & 379 & 4,135 \\
\hline 13 & 12 & 1.50 & 0.00 & 1.00 & 30.0 & 20.7 & 51 & 380 & 4,515 \\
\hline 14 & 13 & 1.50 & 0.00 & 1.00 & 30.0 & 20.7 & 51 & 380 & 4,895 \\
\hline
\end{tabular}




\section{DISTRIBUTION SHEET}

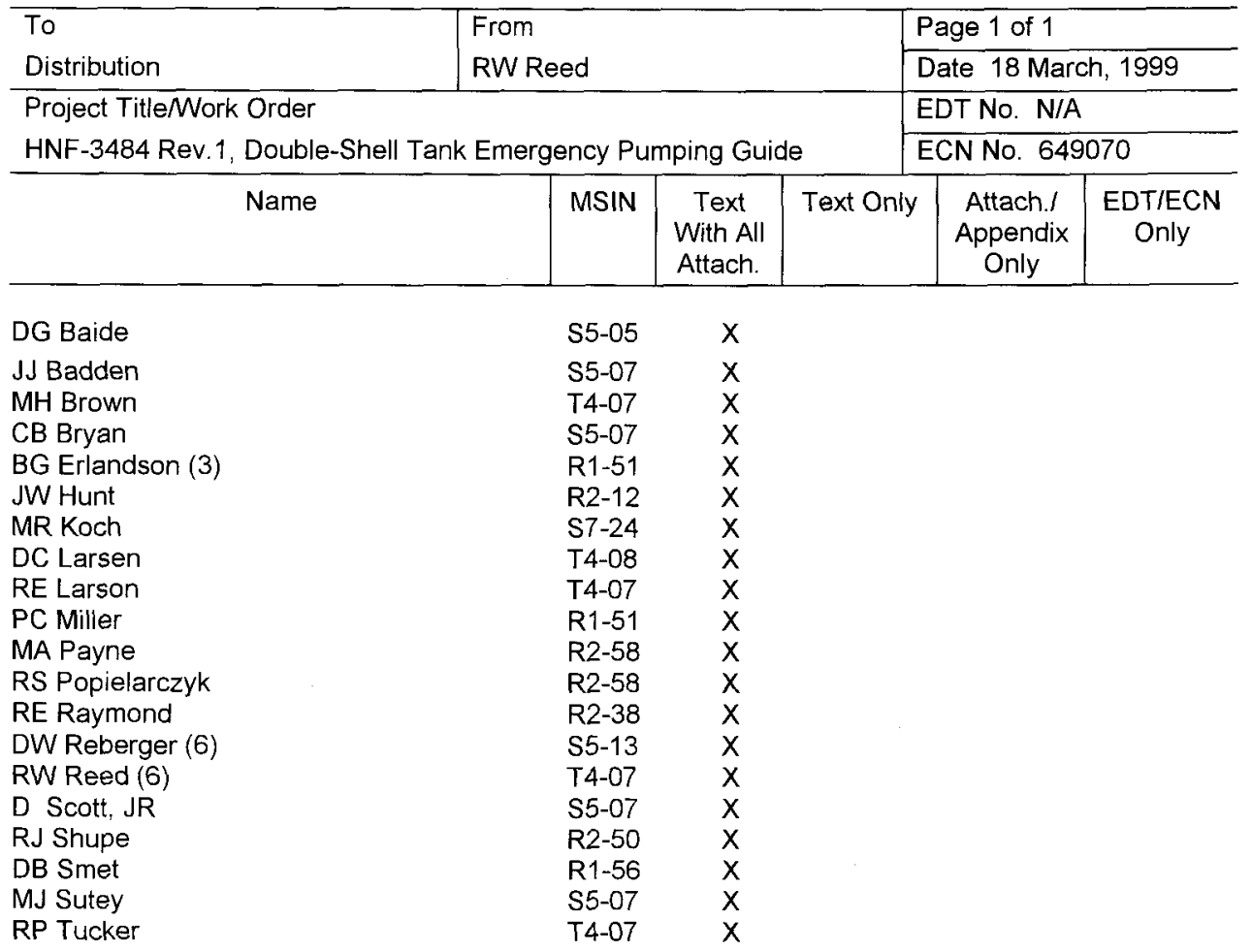

